\title{
PENANGGULANGAN KORUPSI MELALUI PENDEKATAN TEOLOGIS BERBASIS AL-QURAN
}

\section{Corruption Committing Through the Quran-Based Theological Approach}

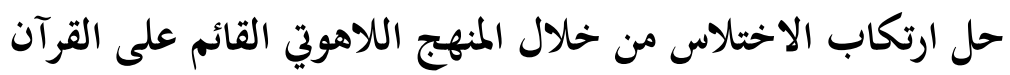

\author{
Muhammad Suaib Tahir', Ali Fikri Noor ${ }^{2}$ \\ ${ }^{1}$ Institut PTIQ Jakartam, Indonesia \\ 'muhammadsauaibtahir@ptiq.ac.id \\ ${ }^{2}$ Sekolah Tinggi Ilmu Ushuluddin Daarul Hikmah Bekasi, Indonesia \\ ªlifikri@gmail.com
}

\begin{abstract}
Abstrak:
Penelitian ini menyimpulkan bahwa penanggulangan korupsi dengan pendekatan konvensional yang non-teologis mengalami kebuntuan, yang disebabkan oleh krisis moral, identitas, dan situasi sosial, dan propaganda kelompok yang mengutamakan strategi penanggulangan korupsi dengan pendekatan perbaikan aturan perundang-undangan daripada pendekatan teologis. Pendekatan konvensional yang non-teologis tersebut selama ini ternyata tidak efektif, sebab ia hanya bersifat exterior superficial (sațiyyun wa zähiriyyun), bukan solusi yang mendalam, yaitu solusi yang mencapai hingga masuk ke kedalaman substansi permasalahan, yakni pendekatan teologi atau agama. Perspektif al-Qur'an dalam penanggulangan korupsi ditemukan melalui tiga strategi, yaitu: detektif, preventif, dan represif. Strategi detektif dan preventif ditempuh melalui tiga cara: penguatan akidah, penguatan kalbu, dan penguatan moralitas. Sedangkan strategi represif ditempuh melalui empat cara: penguatan lembaga pengawasan (al-hisbah), penguatan hukum yuridis dan dunia peradilan, penguatan masyarakat, dan penguatan aspek religiositas. Sementara strategi detektif, preventif, dan represif secara keseluruhan ditempuh melalui cara penguatan nilainilai teologis. Metode yang digunakan dalam penelitian ini adalah metode kualitatif, berbasis riset kepustakaan, ayat-ayat al-Qur'an, publikasi berbentuk hasil penelitian, jurnal, seminar, dan artikel. Sedangkan metode penafsiran yang digunakan adalah metode tafsir tematik (tafsīr mawdūî), baik saat menganalisa permasalahan dari sudut pandang teologis maupun ketika menggunakan ayat-ayat al-Qur'an.
\end{abstract}

Kata Kunci: Korupsi, Teologi, Al-Qur'an

\section{Abstract:}

This study concludes that overcoming corruption with a non-theological conventional approach is deadlocked, which is caused by a moral crisis, identity, and social situation, and group propaganda that prioritizes corruption prevention strategies with an approach to improving legislation rather than theological approach. The conventional, non-theological approach has so far turned out to be ineffective, because it is only superficial (sathiyyun wa zähiriyyun), not a deep solution, that is, a solution that reaches deep into the substance of the problem, namely 
theological or religious approach. The perspective of the Qur'an in dealing with corruption is found through three strategies, namely: detective, preventive, and repressive. Detective and preventive strategies are pursued in three ways: strengthening faith, strengthening the heart, and strengthening morality. Meanwhile, the repressive strategy is pursued in four ways: strengthening supervisory institutions (al-hisbah), strengthening juridical law and the judiciary, strengthening communities, and strengthening aspects of religiosity. Meanwhile, the detective, preventive, and repressive strategies as a whole are taken through strengthening theological values. The method used in this study is a qualitative method, based on library research, verses of the Qur'an, publications in the form of research results, journals, seminars, and articles. While the interpretation method used is the thematic interpretation method (tafsīr mawdū'î), both when analyzing problems from a theological point of view and when using verses of the Qur'an.

Keywords: Corruption, Theology, Al-Qur'an

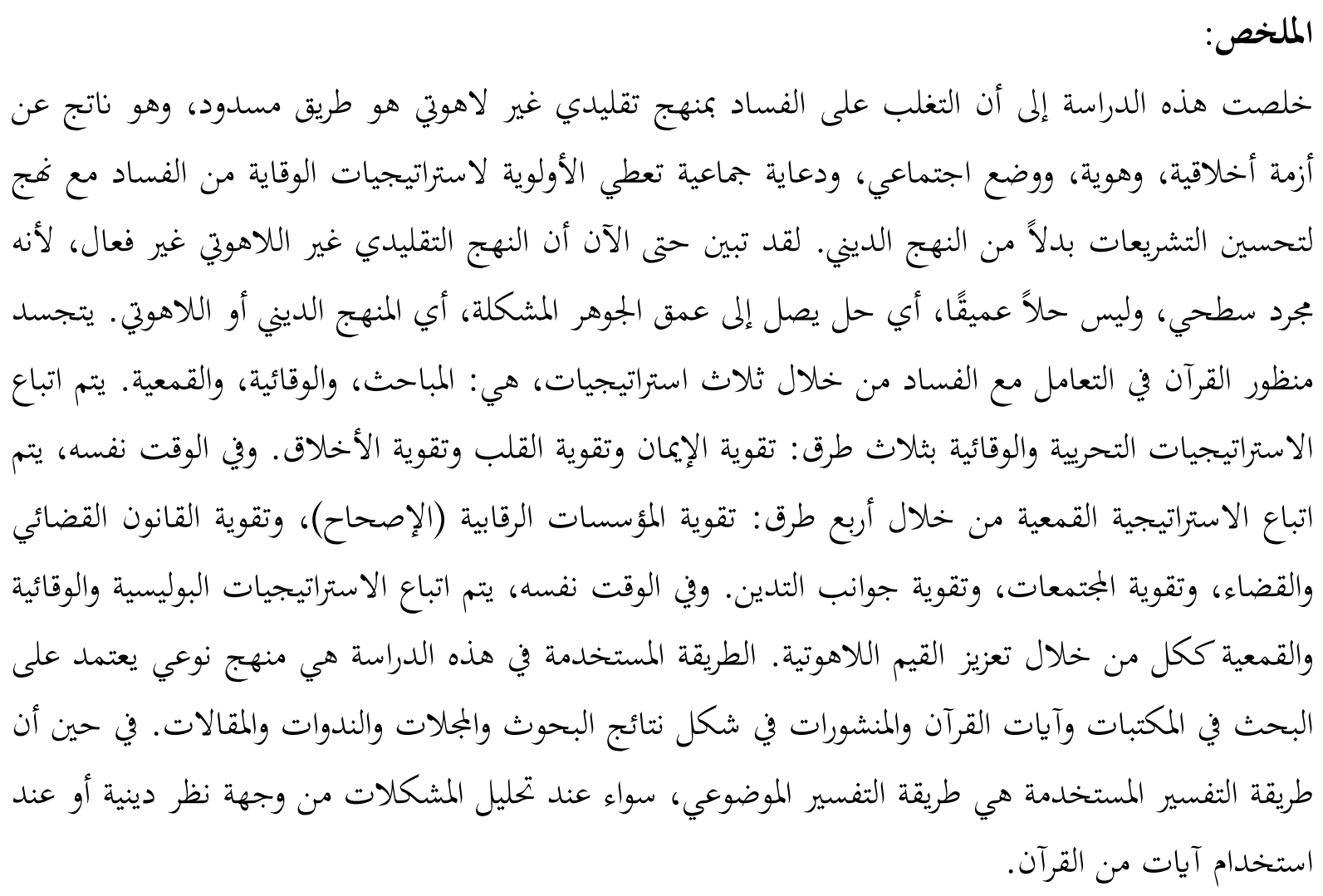

الكلمات المفتاحية: الفساد، التوحيد، القرآن.

\section{Pendahuluan}

Isu korupsi menjadi salah satu isu global yang diperbincangkan masyarakat dunia saat ini. Masalah solusi korupsi pula telah banyak menarik perhatian masyarakat dunia, sehingga berbagai diskusi ilmiah dan akademik, penelitian, survey, makalah, dan paper telah banyak diketengahkan untuk membahas seputar masalah ini, mulai dari penyebab korupsi, konsekuensinya, tipologinya, ruang lingkupnya, 
hingga aksi-aksi korektif yang dapat ditawarkan sebagai jawaban solutif tentang permasalahan ini.

Menurut data dan laporan Transparency International dalam Indeks persepsi Korupsi pada tahun 2016 (Corruption Perceptions Index) Indonesia menempati urutan atau ranking 90/176, dengan score angka 37/100. ${ }^{1}$ Angka ini menunjukkan bahwa di dalam urutan negara-negara terbersih dari korupsi, Indonesia menempati urutan ke 9o dari 176 negara-negara lainnya. Sementara Denmark menempati ranking pertama dalam negara terbersih dari korupsi di dunia, kemudian setelahnya adalah New Zealand, Finland, Sweeden, Switzerland, Norway, Singapore, dan seterusnya. ${ }^{2}$

Korupsi adalah salah satu masalah terbesar ${ }^{3}$ yang dihadapi masyarakat Indonesia sekarang ini, meski pemberantasannya semakin meningkat namun belum terlihat tanda-tanda yang meyakinkan bahwa masalah ini dapat segera di atasi. Indonesia tetap negara yang paling tinggi tingkat korupsinya di seluruh dunia. Demikian ungkapan Azyumardi Azra. ${ }^{4}$ Fenomena ini tentunya merupakan sesuatu yang sangat menyedihkan dan ironis di saat yang sama, di tengah masyarakat dunia dengan jumlah populasi muslim terbesar di dunia, justru kejahatan korupsi di Indonesia dapat tumbuh subur dan menjamur bahkan berkembang secara massif.

Munculnya problematika tentang solusi korupsi disinyalir dari akibat beberapa faktor, pertama: secara umum karena pemahaman yang kurang komprehensif tentang pemahaman teks keagamaan, dan minimnya pengetahuan tentang teologi Islam, yaitu tauhìd 'ubūdiyah (tauhìd ulūhiyah) yang merupakan tujuan inti dari diciptakannya manusia berikut dengan semua aktivitas kehidupan mereka, aktivitas perekonomian, perpolitikan, pemerintahan, manajemen, pendidikan dan pengajaran, perdagangan, jual-beli, bisnis, dan sebagainya. ${ }^{5}$ Kedua: secara umum, teologi dianggap hanya hubungan manusia dengan Tuhannya dalam ibadah ritual, sehingga tidak efektif menanggulangi persoalan sosial, termasuk korupsi. Ketiga: Secara umum pula, good governance tidak dikaitkan dengan sisi teologis atau agama. Keempat: secara umum pula teologi tidak dikaitkan dengan solusi masalah-masalah sosial, di antaranya korupsi. Kelima: secara umum belum meratanya di tengah masyarakat muslim tentang wawasan keberagaman yang integratif atau menyatu, yakni wawasan keberagamaan yang menyatukan antara hubungan horizontal dan vertikal ${ }^{6}$, sehingga mengakibatkan

${ }^{1}$ Corruption perceptions index 2018, the full data set, dalam https://www.transparency.orgIDN. Diakses pada 7 Januari 2018.

${ }^{2}$ Corruption perceptions index 2018, the full data set, dalam https://www.transparency.orgIDN. Diakses pada 8 Januari 2018.

${ }^{3}$ Ketua the Global Organization of Parliamentarians Against Corruption (GOPAC) Indonesia, Pramono Anung (2014) berkomentar saat memberikan sambutan di pembukaan forum anti korupsi Indonesia keempat di Istana Negara, (Selasa, 10/6/2014): "Saat ini Indonesia menduduki peringkat 64 negara paling korup di dunia. Korupsi menjadi masalah serius bagi bangsa kita, sudah mengkhawatirkan karena kasusnya ada di berbagai kalangan mulai dari eksekutif, legislatif, yudikatif bahkan swasta. IPK Indonesia di peringkat 64 negara paling korup. Artinya, kita masih berhadapan dengan banyak kasus korupsi. Lihat: Esthi Maharani, Indonesia peringkat 64 Negara Paling korup”, dalam www.Republika co.id, Selasa, 10 June, 2014, 13:32 WIB. Diakses pada 8 Januari 2018.

${ }^{4}$ Azyumardi Azra, Korupsi Dalam Perspektif Good Governance, Jurnal Kriminologi Indonesia 2, no. $1(2002): 31$.

5 Tujuan diciptakannya manusia adalah untuk beribadah dan mengesakan Allah swt (Q.S. azZariyat/51: 56-58, Yasin/36: 61, al-Hijr/15: 99).

${ }^{6}$ Point ini adalah hasil arahan dan masukan dalam diskusi penulis dengan bapak DR. Abdul Mu'id Nawawi, M.A, dosen dan Kaprodi Tafsir dan Hadits Pascasarjana, PTIQ, di Jakarta, tanggal al-\$urhan: Kajian Ilmu dan Pengembangan Budaya Al-Qur'an, Vol. 20, No. 2, Desember 2020: 216-249| 218 
solusi dan pendekatan penanggulangan korupsi selama ini tidak efektif, sebab ia hanya bersifat exterior superficial (sathiyyun wa dza>hiriyyun), bukan solusi yang mendalam, yaitu solusi yang mencapai hingga masuk ke kedalaman substansi permasalahan, yakni pendekatan teologi atau agama.

Yūsuf al-Qarḍāwi menjelaskan bahwa tugas utama manusia pada kosmos ini adalah menjawab pertanyaan-pertanyaan ini, mengapa saya ada?, apa tugas dan fungsi saya di kosmos ini?, dan apakah misi (risalah) saya pada kehidupan ini? atau dengan ungkapan lainnya dari manakah saya berasal?, akan kemanakah saya?, dan untuk apa saya ada?.?

Hal-hal inilah yang terlihat sering luput dari benak banyak orang di saat mereka melakukan korupsi dan penyimpangan, mereka lupa dengan tiga pertanyaan ini berikut jawabannya, yang mana jika mereka mengetahui dan menghayati jawabannya, niscaya segala bentuk korupsi dan manipulasi akan dapat dijauhkan dari semua aktivitas mereka.

Sayid Qutub mencatat bahwa hakikat ibadah itu adalah lebih umum dan lebih luas cakupannya dari sebatas menunaikan syiar-syiar peribadatan seperti salat, zakat, haji, dan puasa. Ibadah itu meliputi setiap sebutan nama dari aktivitas atau gerakan zahir dan maknawi (bathin), yang dapat menaikkan derajat kehidupan dan mendatangkan kebahagiaan manusia, dan selama itu semua sesuai dengan manhaj Robbani (peraturan/kurikulum Tuhan), dan tempat tujuannya adalah mengesakan Allah dengan uluhiyah-Nya, dan pengakuan untuk-Nya dengan beribadah. ${ }^{8}$

Muhammad Abdullah Darraz juga mengatakan tentang fungsi agama9: "ad-dīn (agama) adalah keyakinan terhadap eksistensi (wujud) zat atau zat-zat gaib yang maha tinggi, zat tersebut memiliki wewenang untuk mengurus dan mengatur urusan yang berkenaan dengan nasib manusia, dan keyakinan yang akan memotivasi manusia untuk bermunajat kepada zat yang agung itu dengan perasaan cinta maupun takut, dan dalam bentuk ketundukan dan pengagungan (peribadatan)". ${ }^{10}$ Dengan demikian melakukan aktivitas perpolitikan dan pengelolaan negara oleh para badan legislative, eksekutif, dan yudikatif, serta peran serta rakyat secara keseluruhan di dalam mengawal berjalannya roda kekuasaan dan pemerintahan secara dinamis, amanah, akuntabel, jujur, transparan, dan terhindar dari praktik-praktik koruptif, manipulatif,

22/9/2019, penulis mengucapkan ribuan terima kasih atas arahan dan masukannya yang sangat berharga.

${ }^{7}$ Yusuf al-Qardawi, al-'Ibadah Fi al-Islām (Beirut: Mu'assasah ar-Risalah, 1399 M/ 1979 M), 1320.

${ }^{8}$ Sayid Qut\{ub, Fi Zilāli Al-Qur'ān (Kairo: Dar asy-Syuruq, t.th), 3387.

${ }^{9}$ Dalam sebuah dialog penulis, Direktur Pasca Sarjana PTIQ, Jakarta, Prof. Dr. M. Darwis Hude, M.si mengatakan di STPDN (Sekolah Tingi Pemerintahan Dalam Negeri) ada seorang mahasiswa beragama Hindu yang tidak mau melakukan kekerasan kepada adik-adik yuniornya, dengan keyakinan jika ia melakukannya, maka hukum karma akan menimpanya. Perasaan tsb tentunya adalah juga bagian dari sikap beragama (teologis), yang jika para pelaku kejahatan korupsi meyakini adanya konsep agama Islam tentang "al-Jaza' min Jinsi al-'amal", (balasan itu sebanding dengan amal perbuatannya), maka mereka tidak akan pernah melakukan kejahatan dan pelanggaran .

${ }^{10}$ Muhammad Abdullah Darraz, Ad-Din, (t.d), 49, dan Buku Panduan Pembinaan Mental Nasional, Direktorat Jenderal Bea dan Cukai, (t.d), 177 .

219 | atßurhan. Kajian Ilmu dan Pengembangan Budaya Al-Qur'an, Vol. 20, No. 2, Desember 2020: 216-249 
dan money politic adalah bagian dari ibadah itu sendiri, yakni tauhi>d ulūhiyah itu sendiri atau penghambaan manusia kepada penciptanya."

Diskursus tentang solusi penanggulangan korupsi pada belakangan ini disinyalir relatif ramai dibicarakan oleh para pakar, mulai para pakar dan penggiat hukum dan juga hingga pemerhati masalah politik dan pemerintahan.

Adalah Azyumardi Azra, menurutnya konsep dan langkah-langkah strategis di dalam penanggulangan korupsi adalah dengan cara mengembangkan kemampuan mengartikulasikan berbagai konsekwensi korupsi terhadap sistem ekonomi, politik dan sosial, kemampuan ini dinilai penting untuk melibatkan kelompok-kelompok kepentingan agar membangun koalisi reformasi yang bertujuan membangun good governance. ${ }^{2}$ Tentang strategi pemberantasan korupsi nasional, Ahmad Badjuri mencatat: hasil studi komprehensif dan pengkajian oleh BPKP yang dituangkan di dalam buku "Strategi Pemberantasan Korupsi Nasional" menyimpulkan bahwa salah satu sebab kegagalan pemberantasan korupsi, ialah lemahnya aparat pemerintah yang menangani korupsi. Hasil study tersebut didokumentasikan dalam strategi pemberantasan KKN yang dikelompokkan menjadi: 1. strategi preventif, yang menguraikan langkah-langkah yang harus dilakukan agar semaksimal mungkin dapat mencegah terjadinya korupsi. 2. strategi detektif, yang menguraikan langkah-langkah yang harus dilakukan bila suatu perbuatan korupsi yang sudah telanjur, terjadi, maka semaksimal mungkin korupsi tersebut dapat diindentifikasikan dalam waktu yang sesingkat-singkatnya. 3. strategi represif, menguraikan langkah-langkah yang harus dilakukan agar perbuatan korupsi yang sudah berhasil diidentifikasi, semaksimal mungkin dapat diproses menurut ketentuan hukum secara cepat, tepat, dan tingkat kepastian hukum yang tinggi. ${ }^{13}$

Berdasarkan laporan dan data strategi pemberantasan korupsi nasional seperti yang disebutkan di atas, kita menemukan strategi tersebut lebih tertumpu pada aspek pendekatan yuridis atau hukum saja, di mana kita tidak menemukan adanya suatu terobosan baru, yaitu strategi penanggulangan dan pemberantasan korupsi melalui pendekatan teologis yang sebenarnya sangat krusial, substansial, dan esensial, di mana ia merupakan upaya penyembuhan dari akar permasalahan korupsi itu sendiri (healing from the roots).

Vito Tanzi, menyimpulkan tentang cara-cara upaya memerangi korupsi (pada point VII: The Fight Against Corruption And The Role Of The State):

"Dikarenakan kompleksitasnya fenomena, maka perang melawan korupsi harus dilakukan dengan pendekatan banyak cara/sisi (many fronts), ini adalah peperangan yang tidak dapat dimenangkan hanya dalam hitungan beberapa bulan saja, atau bahkan beberapa tahun. Kesalahan terbesar yang dapat dilakukan adalah hanya berjalan dan fokus atas strategi yang bergantung secara besarbesaran atas aksi-aksi pada single area saja, seperti menaikkan gaji bagi para pegawai sektor publik,

${ }^{11}$ Mubin, Fatkhul, and Abd Aziz. "Politik Pendidikan Islam Indonesia: Perlawanan Pesantren Terhadap Hegemoni Pendidikan Barat Era Kolonialisme Belanda." Al Amin: Jurnal Kajian Ilmu dan Budaya Islam 3.1 (2020): 123-136.

${ }^{12}$ Azyumardi Azra, "Korupsi Dalam Perspektif Good Governance”, Jurnal Kriminologi Indonesia 2, no. 1 (2002): 33 .

${ }^{13}$ Ahmad Badjuri, Jurnal Bisnis dan Ekonomi (JBE), maret 2011, hal. 84-96, ISSN: 1412-3126, Vol.18. No. 1, Peranan KPK Sebagai Lembaga Anti Korupsi di Indonesia,

al-ourhan: Kajian Ilmu dan Pengembangan Budaya Al-Qur'an, Vol. 20, No. 2, Desember 2020: 216-249| 220 
atau meningkatkan jumlah hukuman, atau dengan menciptakan kantor anti korupsi, atau yang lainnya, lalu memperkirakan hasilnya dengan cepat." ${ }^{\prime 4}$

Susan Rose Ackerman berpandangan (di dalam bab Causes and Consequences of Corruption) bahwa sebab-sebab korupsi adalah karena tiga hal faktor, yakni Incentives, personal ethics, dan Institutions, Faktor Incentives mencakup: low salaries, monopoly power, discretion, lack of accountability, sementara faktor Institutions mencakup: political structure, legal structure, rule of law, dan culture. Adapun konsekuensi korupsi, ia mencakup: low economic growth, low investment, inflation, monetary devaluation, tax evasion, high inequality, low trust, poor education, lowquality infrastructure, high crime rates, trafficking, greater environmental harms, increased health and safety risk. ${ }^{15}$

Teori-teori yang berkembang di kalangan penulis barat adalah bahwa korupsi itu disebabkan dan dilatarbelakangi oleh beberapa faktor yang multi kompleks. Menurut teori Robert Klitgaard, penyebab korupsi adalah monopoli kekuatan oleh pimpinan (monopoly of power) ditambah dengan besarnya kekuasaan yang dimiliki (discretion of official) dan tanpa adanya pengawasan yang memadai (minus accountability), maka hal tersebut menjadi pendorong terjadinya korupsi. Perubahan sistem pemerintahan dari sentralistik menjadi otonomi daerah telah menggeser praktik korupsi yang dahulu hanya didominasi oleh pemerintah pusat kini menjadi marak terjadi di daerah. Hal ini selaras dengan teori Klitgaard bahwa korupsi mengikuti kekuasaan. ${ }^{16}$

Sementara teori Jack Bologne (dalam teorinya: GONE), menyatakan: akar penyebab korupsi ada 4 (empat), yaitu: A) Greedy (Keserakahan), berkaitan dengan adanya perilaku serakah yang secara potensial ada pada diri setiap orang. B) Opportunity (kesempatan), berkaitan dengan keadaan organisasi atau instansi atau masyarakat yang sedemikian rupa sehingga terbuka kesempatan bagi seseorang untuk melakukan korupsi. C) Need (kebutuhan), berkaitan dengan faktor-faktor yang dibutuhkan oleh individu-individu untuk menunjang hidupnya. D) Exposure (pengungkapan), berkaitan dengan tindakan-tindakan atau hukuman yang tidak memberi efek jera pelaku maupun masyarakat pada umumnya. ${ }^{17}$

Teori Ramirez Torez menyatakan: bahwa korupsi adalah kejahatan kalkulasi atau perhitungan (crime calculation) bukan hanya sekadar keinginan (passion). Seseorang akan melakukan korupsi jika hasil yang didapat dari korupsi lebih tinggi dan lebih besar dari hukuman yang didapat, serta kemungkinan tertangkapnya yang relatif kecil. ${ }^{18}$

${ }^{14}$ Vito Tanzi, "Corruption aroud the world: Causes, Consequences, Scope, and Cures", dalam IMF Working paper, International Monetery Fund, May 1998, hal. 30. Diakses pada 8 Januari 2018.

${ }^{15}$ Rose-Ackerman, Susan, Corruption and Government: Causes, Consequences, and Reform (New York: Cambridge University Press, 1992).

${ }^{16}$ Bambang Waluyo, "Optimalisasi Pemberantasan Korupsi Di Indonesia”, Jurnal Yuridis o1, no. 2 (2014): 14. Dan: "memahami-korupsi-untuk-tidak korupsi", dalam http://Sutarjo7o.wordpress.com/2011/12/22. Diakses pada 8, Januari, 2018. Dan: Robert Klitgaard, Ronald Maclean Abaroa, H. Lindsey Parris, Corrupt Cities: a practical Guide to cure and prevention (California: ICS Press, 2000), 26.

${ }^{17}$ Bambang Waluyo, "Kejaksaan Agung Republik Indonesia" Optimalisasi Pemberantasan Korupsi Di Indonesia", Jurnal Yuridis 1, no. 2 (2014): 174.

${ }_{18}$ Bambang Waluyo, "Kejaksaan Agung Republik Indonesia: Optimalisasi Pemberantasan Korupsi Di Indonesia", 174.

221 | al @urhan: Kajian Ilmu dan Pengembangan Budaya Al-Qur'an, Vol. 20, No. 2, Desember 2020: 216-249 
Teori kebutuhan Abraham Maslow. Maslow menggambarkan hierarki kebutuhan manusia ibarat bentuk piramida. Pada tingkat dasar adalah kebutuhan yang paling mendasar. Semakin tinggi hierarki kebutuhan tersebut semakin kecil keharusan untuk dipenuhi. Teori kebutuhan Maslow tersebut menggambarkan hierarki kebutuhan dari paling mendasar (bawah) hingga naik paling tinggi adalah aktualisasi diri. Kebutuhan paling mendasar manusia adalah sandang dan pangan (physical needs). Selanjutnya kebutuhan keamanan adalah perumahan atau tempat tinggal, kebutuhan sosial adalah berkelompok, bermasyarakat, berbangsa. Ketiga kebutuhan paling bawah adalah kebutuhan utama (prime needs) setiap orang. Setelah kebutuhan utama terpenuhi, kebutuhan seseorang akan meningkat kepada kebutuhan penghargaan diri, yaitu keinginan agar kita dihargai, berperilaku terpuji, demokratis dan lainnya. Kebutuhan paling tinggi adalah kebutuhan pengakuan atas kemampuan kita, misalnya kebutuhan untuk diakui sebagai kepala, direktur maupun walikota yang dipatuhi bawahannya. ${ }^{19}$

Teori Vroom menyatakan: bahwa terdapat hubungan antara kinerja seseorang dengan kemampuan dan motivasi yang dimiliki. Berdasarkan teori Vroom tersebut kinerja (performance) seseorang merupakan fungsi dari kemampuannya (ability) dan motivasi (motivation). Kemampuan seseorang ditunjukkan dengan tingkat keahlian (skill) dan tingkat pendidikan (knowledge) yang dimilikinya. Jadi, dengan tingkat motivasi yang sama seseorang dengan skill dan knowledge yang lebih tinggi akan menghasilkan kinerja yang lebih baik. Hal tersebut terjadi dengan asumsi variabel $\mathrm{M}$ (motivasi) adalah tetap. Tetapi Vroom juga membuat fungsi tentang motivasi, yaitu motivasi seseorang akan dipengaruhi oleh harapan (expectation) orang yang bersangkutan dan nilai (Value) yang terkandung dalam setiap pribadi seseorang. Jika harapan seseorang adalah ingin kaya, maka ada dua kemungkinan yang akan dia lakukan, jika nilai yang dimiliki positif, maka dia akan melakukan hal-hal yang tidak melanggar hukum agar bisa menjadi kaya. Namun jika dia seorang yang memiliki nilai negatif, maka dia akan berusaha mencari segala cara untuk menjadi kaya, salah satunya dengan melakukan korupsi. ${ }^{20}$

Aziz Syamsuddin berpandangan terjadinya tindak pidana korupsi adalah karena disebabkan faktor-faktor berikut: 1 . Lemahnya pendidikan agama, moral, dan etika. 2. Tidak adanya sangsi yang keras terhadap pelaku korupsi. 3. Tidak adanya suatu system pemerintahan yang transparan (good Governance). 4. Faktor ekonomi. 5. Manajemen yang kurang baik dan tidak adanya pengawasan yang efektif dan efisien. 6 . Modernisasi yang menyebabkan pergeseran nilai-nilai kehidupan yang berkembang dalam masyarakat. ${ }^{21}$

Diantara para pakar dan ilmuwan muslim Timur Tengah yang cukup gencar menawarkan konsep solusi perbaikan masalah penyakit sosial dari akarnya (healing from the roots) dan termasuk di dalamnya penyakit korupsi adalah Yūsuf al-Qardawi, Muhammad Tahir Ibnu Asyūr, Hasan al-Bannā, dan Sayid Abu al-Hasan Ali al-Hasani

${ }^{19}$ Bambang Waluyo (Kejaksaan Agung Republik Indonesia), "memahami korupsi untuk tidak korupsi”, dalam http://Sutarjo7o.wordpress.com. Diakses pada 8, Januari, 2018. Dan Bambang Waluyo, “Optimalisasi Pemberantasan Korupsi Di Indonesia”, Jurnal Yuridis 1, no. 2 (2014): 175.

${ }^{20}$ Bambang Waluyo, "Optimalisasi Pemberantasan Korupsi Di Indonesia”, 174.

${ }^{21}$ Aziz Syamsuddin, Tindak Pidana Khusus (Jakarta: Sinar Grafika, 2011), 14. Abd Aziz , Sastra dan Etika (Studi Etika Sosial atas Diwan 'Abd al-Qadir al-Jilani), (Tangerang Selatan: Yapin An-Namiyah, 2021), vol. 1.

al-@urhan: Kajian Ilmu dan Pengembangan Budaya Al-Qur'an, Vol. 20, No. 2, Desember 2020: 216-249| 222 
an-Nadwi. Dalam hal ini mereka memiliki kesamaan gagasan dan konsep terkait cara-cara solutif bagi penanganan penyakit-penyakit sosial, dan pemberantasan kriminalitas yang melanda pemerintahan dan negara-negara dunia Islam.

Penelitian ini dalam menawarkan konsep solusi penanggulangan korupsi melalui pendekatan teologis ini sependapat dengan gagasan-gagasan yang telah dicanangkan oleh banyak ilmuwan dan pakar sebelumnya, yang di antara lain mereka itu adalah: Hasan al-Banna (w.1949 M), Yusuf al-Qardlawi, dan Sayid Abu al -Hasan Ali al-Hasani an-Nadwi (w.1999 M), dan M. Darwis Hude (2017). ${ }^{22}$

Hasan al-Banna telah mengemukakan konsep dasarnya terkait pemahaman yang benar tentang "komprehensifitas ajaran agama Islam yang mencakup seluruh aspek kehidupan”, yang selanjutnya beliau rangkum prinsip-prinsip dasar pemahaman tersebut dalam bingkai "al-ușūl al-isyrīn", yaitu prinsip-prinsip yang berjumlah dua puluh, di mana prinsip pertamanya adalah: "Islam adalah sistem yang menyeluruh (komprehensif), mencakup seluruh aspek kehidupan, dia adalah negara dan tanah air, atau pemerintahan dan umat, moral dan kekuatan, atau kasih sayang dan keadilan, wawasan dan undang-undang atau ilmu pengetahuan dan peradilan, materi dan kekayaan alam, atau penghasilan dan kekayaan, serta jihad dan dakwah, atau pasukan dan pemikiran, sebagaimana juga ia adalah akidah yang murni dan ibadah yang benar, tidak kurang dan tidak lebih". ${ }^{23}$

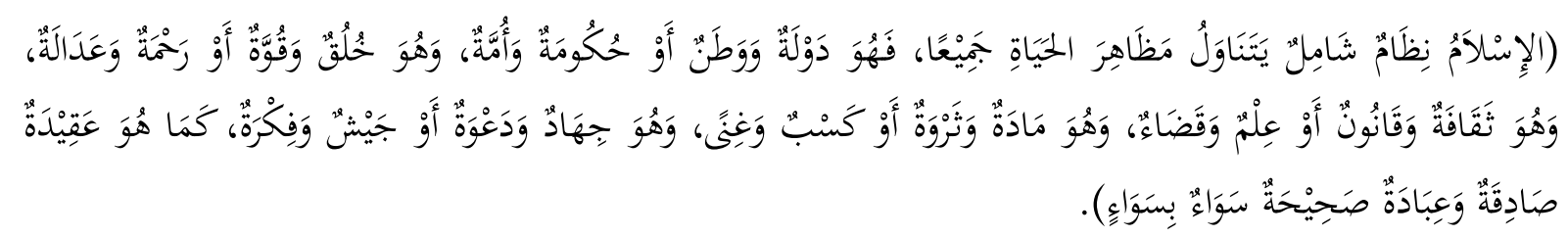

Gagasan dan pemikiran Yusuf al-Qardlāwi itu populer dengan konsep: "hatmiyyah al-hâal al-islāmī", yakni keharusan menggunakan solusi Islami, sebagai sebuah konsep dasar bagi gerakan reformasi atau perbaikan sosial adalah sebuah keniscayaan.

Konsep dasar tentang perbaikan dan reformasi sosial yang ditawarkan olehnya adalah: "masyarakat muslim itu tidak akan pernah dapat dibangun atau diwujudkan dengan hanya melakukan perbaikan aturan undang-undang dan hukum (tasyrī') saja, akan tetapi harus melalui dua media atau pendekatan lainnya, yakni pertama: dakwah dan penyadaran (teologis), kemudian kedua adalah pendidikan dan pengajaran, dan hal tersebut adalah dilakukan sebelum perbaikan aturan hukum dan perundangundangan. ${ }^{24}$

${ }^{22}$ Ia berpandangan: "apabila negara dipimpin oleh orang orang yang tidak memiliki kemampuan, integritas, akhlak, dan orientasi masa depan untuk kesejahteraan bangsanya maka negara dan bangsa itu tidak akan maju, hanya mereka yang memiliki integritas dan konsistensi pada kebenaran yang mampu melakukan tugas-tugas itu. Secara garis besar, pemuda dapat mengambil peran dalam dua aspek pembangunan. Yang pertama, aspek pembangunan rohani (moral-spiritual), dan yang kedua, aspek pembangunan jasmani (fisik-material)". M. Darwis Hude, Logika al-Qur'an: Pemaknaan Ayat Dalam Berbagai Tema, editor. Abd. Muid, N (Jakarta: Penerbit Eurabia, PT. Nagakusuma Media Kreatif, 2017), 149-150.

${ }^{23}$ Muh\{ammad Abdullāh al-Khatīb, Muhammad Abdul Halim Hamid, Nazarat fi Risalati atTa'alim, (t.d), 47.

${ }^{24}$ Yusuf al-Qardawi, Malāmih al-Mujtama' al-Muslim Allazi Nunsyiduhu (Beirut: Mu'assasah arRisalah, $2001 \mathrm{M} / 1422 \mathrm{H}), 186$,

223 | al-@urhan: Kajian Ilmu dan Pengembangan Budaya Al-Qur'an, Vol. 20, No. 2, Desember 2020: 216-249 
Beliau juga menyatakan konsep dasarnya tentang perbaikan: Sesungguhnya sebatas melakukan perbaikan atau perubahan undang-undang saja semata, hal itu tidak akan dapat menciptakan masyarakat muslim, dan sedangkan melakukan perbaikan atau perubahan terhadap sesuatu (aspek teologis) yang terdapat di dalam jiwa-jiwa itu adalah sebagai asas, dan sesuatu yang lebih besar yang dapat membantu memperbaiki dan mengubah sesuatu yang ada di dalam jiwa-jiwa itu adalah iman itu sendiri. Iman/teologi adalah sesuatu yang menciptakan sesuatu lainnya untuk manusia, iman/teologi adalah yang mampu menggariskan baginya sasaran dan tujuan hidupnya, serta kaidah-kaidah kehidupan, dan mampu menggambarkan tentang balasan, baik balasan di dunia dan balasan di Akhirat. ${ }^{25}$

Pada kesempatan lainnya beliau mengemukakan pandangannya tentang konsep dan solusi perubahan: "para pemimpin-pemimpin revolusi di negeri-negeri dunia Arab dan Islam itu telah melupakan unsur morality dan spiritual di dalam perubahan, padahal sesungguhnya setiap revolusi sosial yang tidak diawali dan dibarengi dengan revolusi spiritual, pemikiran dan kejiwaan, tiada disangsikan dia itu adalah sebuah revolusi yang akan berujung dengan kegagalan dan kerugian”. ${ }^{26}$ Menurutnya pula:

"Al-Qur'an itu telah menjelaskan hukum sosial, dan meletakkannya di dalam bingkai the firm divine rule (undang-undang ketuhanan yang baku) yang tidak akan berubah dan tergantikan, yakni "Sesungguhnya Allah tidak merobah keadaan sesuatu kaum sehingga mereka merobah keadaan yang ada pada diri mereka sendiri" (Q.S al-Ra'd/13:11), dan makna perubahan spiritual dan jiwa adalah perubahan zat manusia itu sendiri dari suatu keadaan ke suatu keadaan lainnya, perubahan orientasi dan pandangannya, pemikiran-pemikirannya, perasaan-perasaannya, tujuantujuannya dan perubahan keyakinan-keyakinannya (faith/system/ religion). Dan inilah yang disebut dengan "perubahan revolusioner yang hakiki". Sebab ia adalah perubahan yang mengarah kepada spiritual (ar-rūh) dan esensi (al-Jauhar), yang tidak berhenti pada sisi kulit dan luar saja. Perubahan kejiwaan ini tidak akan sempurna kecuali dengan satu cara, yaitu keimanan/teologi." 7

Argumentasi beliau ini dibangun di atas sebuah kenyataan dan kaidah, yaitu karena perbaikan masyarakat itu ketika pada fase era makiyah, yakni era turunnya ayat-ayat al-Qur'an di kota Mekkah adalah dimulai oleh Islam dengan fase dakwah dan tarbiyah (pengajaran), dan ini dilakukan sebelum era madaniyah, yaitu fase perbaikan atau penataan hukum dan undang-undang. Pada era ini kita melihat penataan atau perbaikan hukum itu tercampur dengan tarbiyah juga, yaitu ibarat bercampurnya jasmani dengan ruh. ${ }^{28}$

Hasan al-Bannā (w.1949 M) menawarkan konsepnya tentang solusi atau pendekatan teologis mengenai perbaikan atas kerusakan aturan hukum sosial secara umum, dan termasuk perbaikan penyakit korupsi secara khusus tentunya, yakni melalui tiga pendekatan ini secara sinergis, yaitu: 1. Metode yang benar (al-minhāj assahih), yakni berdasarkan kitabullah dan sunnah rasul-Nya, dan aturan-aturan hukum Islam. 2. Sekelompok para pelakunya, dari komunitas pejuang orang-orang beriman (al-'āmilūn al-mu'minūn), di mana mereka itu menerapkan apa yang mereka pahaminya itu dari agama Allah ini secara serius, dan tidak ada kompromi atau main-

${ }^{25}$ Yusuf al-Qardawi, Malamih al- Mujtama' al-Muslim Allazi Nunsyiduhu, 186.

${ }^{26}$ Yusuf al-Qardawi, al-Hal al-Islami Faridah wa Darurah (Beirut: Muassasah ar-Risalah, 1394 H/1974 M), 23.

${ }^{27}$ Yusuf al-Qardawi, al-Hal al-Islami Faridah wa Darurah, 23-24.

${ }^{28}$ Yusuf al-Qardawi, Malamih al- Mujtama' al-Muslim Allazi Nunsyiduhu, $186 .$.

at-Burhan: Kajian Ilmu dan Pengembangan Budaya Al-Qur'an, Vol. 20, No. 2, Desember 2020: 216-249 | 224 
main di dalamnya. 3. Kepemimpinan politik yang terpercaya/akuntabel, yakni tidak koruptif dan manipulatif (al-qiyādah al-hazimah al-mawșūqu bihā). ${ }^{29}$

Di sisi lainnya konsep solusi penanggulangan korupsi melalui pendekatan teologis juga telah ditawarkan melalui konsep yang telah digagas oleh Muh\{ammad Ta>hir Ibnu Asyūr (w.1973 M), bapak tokoh Maqās\{id Syarī'ah modern (yaitu konsep reformasi individual dan reformasi sosial). Di mana ia berpandangan bahwa konsep Islam di dalam membangun dasar- dasar undang-undang (principles constitution) adalah berbasis atas dua hal, yakni pertama: dasar-dasar reformasi individual, dan kedua: dasar-dasar reformasi sosial. Konsep dasar-dasar reformasi individual itu mencakup: reformasi akidah (islahu al-'aqīdah/ theology reformation), reformasi pemikiran (islāhu at-tafkir/thought reformation), reformasi aktifitas (i\{lahu al'amal/activity reformation), dan pembangunan aspek kejiwaan (ijadu al-wazi' annafsāni). Sedangkan dasar-dasar reformasi sosial itu mencakup: pembentukan pan Islamisme (ijadu al-jāmi'ah al-islāmiyah), pembentukan komunitas Muslimin (ijadu jama'ati al-muslimīn), dan persaudaraan Islamiyah (ukhuwwah islāmiyah). ${ }^{30}$

Di sisi lain penelitian ini juga dimaksudkan sebagai kritik atas konsep solusi penanggulangan korupsi yang dikemukakan oleh para ilmuwan Barat, yaitu sebuah konsep yang kering teologis, namun cukup populer di dalam diskursus ilmiah tentang korupsi, konsep tersebut dikenal dengan teori Jack Bologne (GONE), Robert Klitgaard, Ramirez Torez, dan Abraham Maslow di dalam memandang faktor-faktor yang melatarbelakangi timbulnya praktik korupsi.

Al-Qur'an sebagai kitab suci umat Islam yang menjadi sumber petunjuk/hidayah, ajaran dan nilai, di mana sisi-sisi nilai dan ajarannya akan selalu up to date, sālihun likulli zamānin wa makānin dan diyakini kebenarannya pastilah banyak berbicara tentang pendekatan teologis sebagai sebuah solusi penyakit manusia baik fisik dan mental.

Berikut ini adalah beberapa ayat berikut tema-temanya yang mengisyaratkan tentang pendekatan teologis sebagai suatu sistem komprehensif bagi penanggulangan penyakit kriminal sosial secara umum, dan korupsi secara khusus.

\section{Iman Kepada Allah Dan Urgensitasnya Dalam Pencegahan Korupsi}

Beriman kepada Allah swt memiliki urgensitas dan pengaruh kuat dan besar bagi kehidupan manusia, dan bagi penanggulangan korupsi, sebab beriman kepada Allah swt akan memberikan bekas dan pengaruh dalam perilaku seorang muslim, dalam karakter dan tabiatnya, dan pemikiran-pemikirannya, yang kesemuanya itu akan memberikan pengaruh dan dampak terbesar bagi pencegahan dan pembentengan dari perilaku korupsi. Hal ini sebagaimana ditegaskan di dalam Q.S. Ṭāhā/20:7,

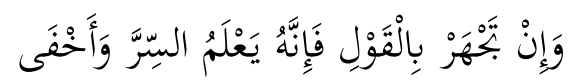

Dan jika kamu mengeraskan ucapanmu, maka sesungguhnya Dia mengetahui rahasia dan yang lebih tersembunyi.

${ }^{29}$ Muhammad Abdullah al-Khatib dan Muhammad Abdul Halim Hamid, Nazarat fi Risalati atTa'alim, 19.

${ }^{30}$ Muhammad Tahir Ibnu Asyur, an-Nizām al-Ijtimā’i fi al-Islām (Kairo: Dar as-Salam, 1431 $\mathrm{H} / 2010 \mathrm{M}), 38-113$.

225 | at \$8urhan: Kajian Ilmu dan Pengembangan Budaya Al-Qur'an, Vol. 20, No. 2, Desember 2020: 216-249 
Pencegahan dan pembentengan dimaksud akan terbangun dalam cara- cara berikut:

a. Terbangun dan terciptanya pengendalian diri/self control (ar-riqābah al-dhātiyah) $)^{31}$ dalam jiwa orang beriman.

b. Terbangunnya salah satu cabang dari cabang-cabang Iman, yaitu moralitas "rasa malu".

c. Menumbuhkan stimulus (perangsang) untuk melakukan amal saleh, sebagaimana difirmankan:

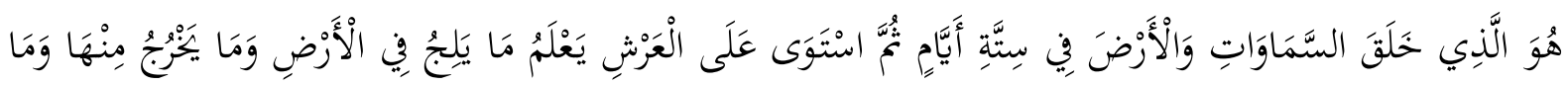

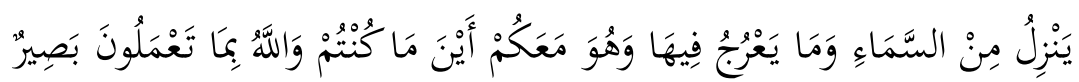

Dialah yang menciptakan langit dan bumi dalam enam masa: Kemudian Dia bersemayam di atas 'arsy 'Dia mengetahui apa yang masuk ke dalam bumi dan apa yang keluar daripadanya dan apa yang turun dari langit dan apa yang naik kepada-Nya, Dan Dia bersama kamu di mana saja kamu berada. Dan Allah Maha Melihat apa yang kamu kerjakan. (Q.S. al-Hadīd/57:4).

Ibnu Kathīr menjelaskan tafsir dan makna ayat ini: Dialah Allah yang mengawasi kalian, menyaksikan seluruh perbuatan kalian di mana saja dan bagaimana saja kondisi kalian, di daratan dan di lautan, pada malam hari atau siang hari, di rumah-rumah atau di gua-gua, seluruhnya sama-sama di bawah ilmu dan pengawasan-Nya, penglihatan serta pendengaran-Nya, Ia mendengar ucapan kalian, melihat tempat kalian, mengetahui rahasia kalian, dan bisikan-bisikan kalian". ${ }^{2}$

\section{Iman kepada Malaikat ${ }^{33}$ dan Urgensitasnya Dalam Pencegahan Korupsi}

Pengaruh dari beriman kepada para malaikat adalah ia akan melahirkan sifat istiqomah pada diri seorang beriman atas perintah Allah swt. Seseorang yang di dalam hatinya merasakan keberadaan para malaikat, dan beriman bahwa mereka itu selalu mencatat dan mengawasinya atas seluruh perilaku, dan ucapannya, para malaikat itu selalu menyaksikan apa saja yang keluar dari pribadi seorang muslim, dipastikan ia akan merasa malu kepada Allah dan malaikat-malaikat-Nya, yang kemudian orang tsb tidak akan melanggar perintah-Nya dan bermaksiat kepada-Nya, baik di dalam kesendirian ataupun keramaian, dikarenakan keimanannya bahwa setiap perilaku dan ucapannya itu akan selalu diawasi, dicatat dan disaksikan oleh-Nya dan oleh malaikat Nya. ${ }^{34}$

${ }^{31}$ Lihat: 'Allamah Sadruddin 'Ali Ibn Ali Muhammad Ibn Abi al-Izz al-Hanafi, tahqiq Ahmad Muhammad Syakir, Syarah al-'Aqidah at-Tahawiyah (Peshawar: Kutub Khānah Rasyīdiyyah, 1413 H/1993 M), 10,

${ }^{22}$ 'Imaduddin Abi al Fidā' Isma'il Ibn Kasir al-Qurasyi ad-Dimasyqi, (Imam Ibnu Katsir), Tafsir al-Qur'an al-Azim (Damaskus: Maktbah Dar al- Faiha, 1414 H/1994 M), 305.

${ }^{33}$ Saleh Ibn Fawzan Ibn Abdullah al-Fawzan, al-Irsyad Ila Shahih al-I'tiqad (Jeddah: Dar Ibnu al-Jauziy, 1421 H), 168-17o. Lihat juga Ibnu Kasir, Tafsir al-Qur'an al-'Azim (Al-Madinah al-Munawwarah: Maktabah al-'Ulum wa al-Hikam, 1413 H/1993 M, jilid 2), 662. Dan: 'Ali Ahmad 'Abdu al-Al at-Tahtawi, al-Hayatu Ba'd al-Mawt (Beirut: Dār al-Kutub al-Ilmiyah, 2005 M), 154.

${ }^{34}$ Muhammad Na'im Yasin, Kitab al-Iman: Arkanuhu, Haqiqatuhu, Nawaaqiduhu (Iskandariyah: Dar Umar ibn al-Khattab, t.th), 28.

alosurhan: Kajian Ilmu dan Pengembangan Budaya Al-Qur'an, Vol. 20, No. 2, Desember 2020: 216-249 | 226 
Dalil yang melandasi hal ini adalah firman-Nya:

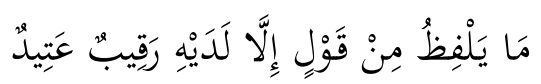

Tiada suatu ucapanpun yang diucapkannya melainkan ada di dekatnya malaikat pengawas yang selalu hadir", (Q.S. Qāf /50:18).

Pengertian lafadz yang keluar dari mulut seorang manusia, di mana malaikat turut mencatatnya- sebagaimana dituturkan oleh Imam Ibnu Katsir dari riwayat Ibnu Abbas - adalah: "ditulis setiap ucapan yang dibicarakan seseorang dari ucapan kebaikan atau keburukan, sehingga ucapannya itu seperti: "aku telah makan”, "telah minum", "telah pergi”, "telah datang”, "telah melihat", juga ditulis oleh malaikat, sampai jika datang hari kamis, maka diperlihatkan oleh Allah swt ucapan seseorang manusia dan perbuatannya itu, lalu ditetapkan dari orang tsb semua yang baik atau yang buruk, dan dibuang yang selainnya. ${ }^{35}$

\section{Imam Kepada Kitab-Kitab-Nya dan Urgensitasnya Dalam Pencegahan Korupsi}

Efek dan pengaruh dari beriman kepada kitab-kitab-Nya, dan termasuk di dalamnya adalah beriman kepada kitab suci Al-Qur'an terhadap perilaku, pencegahan, dan penanggulangan korupsi ini tergambarkan di dalam penjelasan berikut: Kitabkitab yang telah Allah swt turunkan baik Taurat, Zabur, Injil dan al-Qur'an adalah berfungsi sebagai cahaya dan petunjuk kehidupan. Oleh karenanya merasakan hadirnya hati bersama ajaran-ajaran dan petunjuk kitab-kitab suci dan al-Qur'an adalah sebagai pencegah terbesar bagi seseorang dari mendekati perilaku menyimpang, haram, keji dan kotor, dan termasuk adalah perilaku koruptif dan manipulatif. ${ }^{36}$

Hal ini sebagaimana telah ditegaskan di dalam firman-Nya,

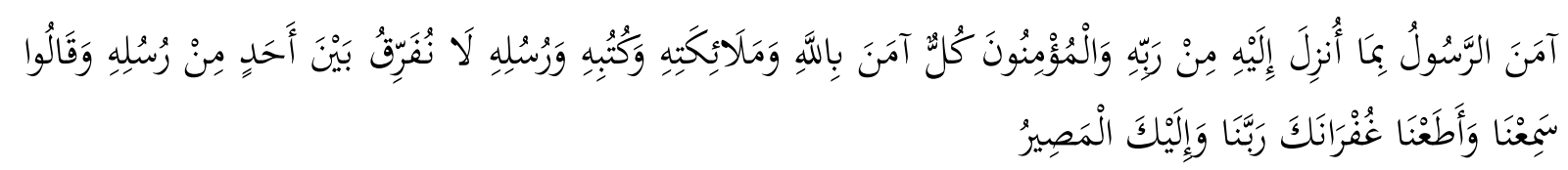

Rasul telah beriman kepada Al Quran yang diturunkan kepadanya dari Tuhannya, demikian pula orang-orang yang beriman. Semuanya beriman kepada Allah, malaikatmalaikat-Nya, kitab-kitab-Nya dan rasul-rasul-Nya. (Mereka mengatakan): "Kami tidak membeda-bedakan antara seseorangpun (dengan yang lain) dari rasul-rasul-Nya", dan mereka mengatakan: "Kami dengar dan kami taat." (Mereka berdoa): "Ampunilah kami ya Tuhan kami dan kepada Engkaulah tempat kembali. (Q.S. al-Baqarah/2 :285).

\section{Imam kepada Rasul-Rasulnya-Nya dan Urgensitasnya Dalam Pencegahan Korupsi}

Beriman kepada para rasul, yaitu manusia teladan dan pilihan akan mendorong seorang muslim untuk selalu mensuri tauladani dan mencontoh mereka di dalam perbuatan kebaikan, kemaslahatan, dan ketaatan, dan mendorongnya untuk menjauhi dari setiap perilaku yang menyalahi dan bertentangan dengan nilai-nilai

\footnotetext{
${ }^{35}$ Ibnu Kasir, Tafsir al-Qur'an al-Azim, jilid IV, 225.

${ }^{36}$ Tariq Ibn Sulaiman al-Bahlal, "Al-Iman wa Dawruhu fi al-Wiqayah min al-Jarimah", Naif Arab University for Security Sciences (1425 H): 104.

227 | at @urhan: Kajian Ilmu dan Pengembangan Budaya Al-Qur'an, Vol. 20, No. 2, Desember 2020: 216-249
} 
keimanan tersebut, dan dari perilaku yang bertentangan dengan kelurusan perilaku serta keindahan aturan agama (way of life). ${ }^{37}$

Terdapat banyak ayat yang berkaitan dengan permasalahan ini, di antaranya adalah:

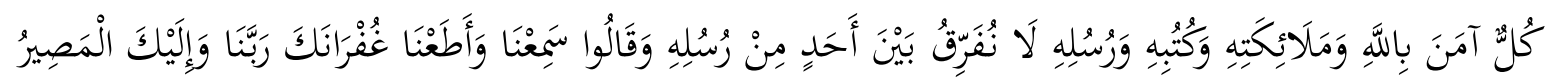

(Mereka mengatakan): Kami tidak membeda-bedakan antara seseorangpun (dengan yang lain) dari rasul-rasul-Nya", dan mereka mengatakan: "Kami dengar dan kami taat." (Mereka berdoa): "Ampunilah kami ya Tuhan kami dan kepada Engkaulah tempat kembali. (Q.S.al-Baqarah/2 :285).

\section{Imam kepada Hari Akhir dan Urgensitasnya Dalam Pencegahan Korupsi}

Beriman kepada Hari Akhir itu memiliki pengaruh yang besar bagi kehidupan manusia, di mana jika ia telah mempercayai adanya Hari Akhir, berikut dengan adanya surga dan neraka, hari perhitungan (hisab), hukuman dan balasan, keberuntungan dan kerugian, hal itu semua akan mempengaruhi seseorang di dalam mengarahkannya, membiasakannya, dan menjadikannya berkomitmen dengan perbuatan-perbuatan baik dan ketakwaan kepada Allah swt. Adalah berbeda antara orang yang tidak mempercayai adanya Hari Pembalasan dengan yang mempercayainya, yang pertama akan lepas kendali dari segala aturan agama, dan akan memilih memperturut hawa nafsunya sekalipun mengundang marabahaya, karena tujuannya adanya selfisme, dan pemuasan hawa nafsu pribadinya, sekalipun dengan menghalalkan segala cara. ${ }^{38}$ Sedangkan yang kedua akan terus berada di dalam koridor aturan hukum, kebenaran, kebaikan, dan kemaslahatan karena keyakinannya terhadap adanya pengadilan yang maha adil, yaitu Allah Swt. ${ }^{39}$

Hal ini telah dipertegas di dalam banyak ayat al-Qur'an, di antaranya:

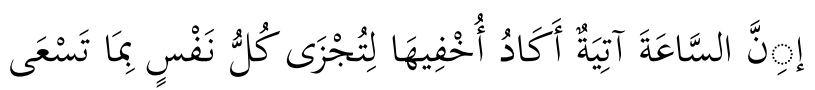

Sesungguhnya hari kiamat itu akan datang Aku merahasiakan (waktunya) agar supaya tiap-tiap diri itu dibalas dengan apa yang ia usahakan. (Q.S. Țāhā/20 :15).

\section{Imam kepada Qadla' dan Qadar-Nya Dan Urgensitasnya Dalam Pencegahan Korupsi}

Di antara makna dan pengertian beriman kepada qadla dan qadar adalah meyakini bahwa apa saja dari setiap kejadian baik takdir baik dan buruk manusia adalah atas seizin dan kehendak Allah swt, dan di dalam kehidupan manusia setiap gerak-geriknya itu tidak dapat keluar dari kekuasaan dan kehendak-Nya, sebagaimana dijelaskan pada ayat berikut:

37 Tariq Ibn Sulaiman al-Bahlal, Al-Iman wa Dawruhu fi al-Wiqayah min al-Jarimah”, 109.

${ }^{38}$ Munif Mahadi Attamimi and Muhammad Hariyadi, "Al-Qur' an Answering the Challenge of

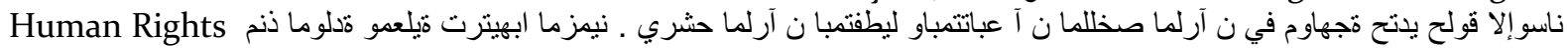

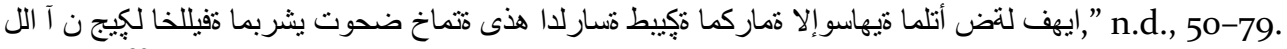

${ }^{39}$ Muhammad Na'im Yasin, Kitab al-Iman: Arkanuhu, Haqiqatuhu, Nawaaqiduhu, 44. at-\$Burhan: Kajian Ilmu dan Pengembangan Budaya Al-Qur'an, Vol. 20, No. 2, Desember 2020: 216-249| 228 


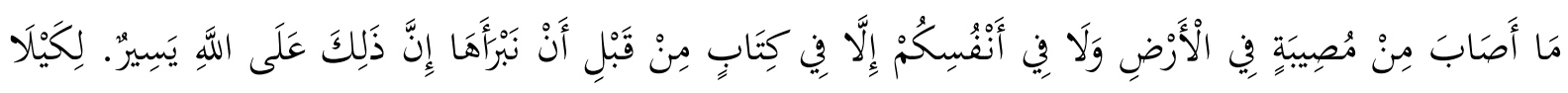

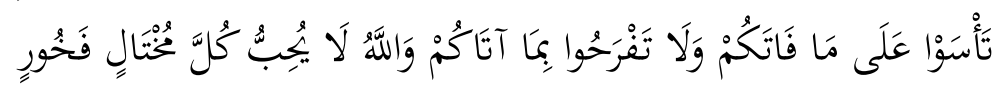

Tiada suatu bencanapun yang menimpa di bumi dan (tidak pula) pada dirimu sendiri melainkan telah tertulis dalam kitab (Lauhul Mahfuzh) sebelum Kami menciptakannya. Sesungguhnya yang demikian itu adalah mudah bagi Allah. Kami jelaskan yang demikian itu) supaya kamu jangan berduka cita terhadap apa yang luput dari kamu, dan supaya kamu jangan terlalu gembira terhadap apa yang diberikan-Nya kepadamu. Dan Allah tidak menyukai setiap orang yang sombong lagi membanggakan diri. (Q.S. alHadīd/57 : 22-23).

Menurut Muhammad Na'im Yasin:

"Seseorang yang jika imannya itu telah terbangun seperti pada ayat yang disebutkan di atas, niscaya Allah swt akan memberikan kepadanya kekuatan yang tidak akan dapat ditembus oleh tipuan atau siasat setan, dan hiasan kriminalitas sekalipun, sebab siasat dan tipuan setan adalah lemah, dan bagaimana yang lemah itu dapat mengalahkan kekuatan orang yang beriman kepada qada dan qadar ?."40

Walhasil Hipotesa penulis adalah: tidak ada solusi atau strategi yang terbaik, dan efektif di dalam memberantas dan menanggulangi korupsi selain menanggulanginya dari akar permasalahannya, yaitu melalui pendekatan teologis berbasis Al-Qur'an, yakni melalui dua media pendekatan: dakwah dan penyadaran (teologis), kemudian pendidikan dan pengajaran.

Konsep dan kaidah ini selain telah diperkuat oleh Yusuf al-Qardlawi, Hasan AlBanna, Sayid Abul Hasan Ali An-Nadwi, Muhammad Tahir Ibnu Asyur, juga telah digagas dan diperkuat pula oleh Imam al-Ghazali (w.505 H), beliau mengemukakan: "Kedudukan ajaran syariat (teologis) adalah ibarat pokok, sedangkan kedudukan aturan hukum perundang-undangan adalah ibarat penjaga.

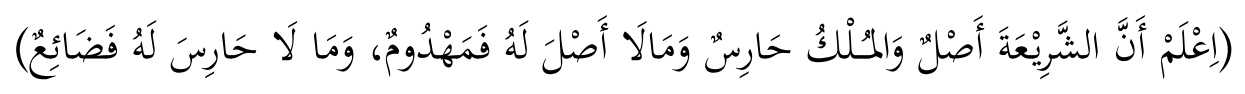

Ketahuilah bahwa Syariat itu adalah pokok dan kekuasaan itu adalah penjaganya, dan sesuatu yang tidak ada pokoknya maka ia akan musnah, dan sesuatu yang tidak ada penjaganya juga akan hilang sia-sia.

Setiap revolusi sosial yang tidak diawali dengan revolusi teologis, yakni revolusi mental spiritual (ruhiyah), pemikiran (fikriyah), dan kejiwaan (nafsiyah), tidak diragukan adalah revolusi yang akan berakhir dengan kegagalan dan kerugian. Di mana Al-Qur'an telah menjelaskan sisi hukum sosial (as-sunnah al-ijtimā’iyah), dan meletakkannya di dalam bingkai undang-undang ilahiah yang ajeg, tidak akan berubah, dan melenceng, yaitu: (Sesungguhnya Allah tidak merobah keadaan sesuatu kaum sehingga mereka merobah keadaan yang ada pada diri mereka sendiri), Q.S. arRa'd/13: $11{ }^{41}$

${ }^{40}$ Muhammad Na'im Yasin, al-iman, arkanuhu, haqiqatuhu, nawaqiduhu (Amman Yordania: Dar al-Furqon, 1424 H), 134, dan Tariq Ibn Sulaiman al-Bahlal, "Al-Iman wa Dawruhu fi al-Wiqayah min al-Jarimah", Naif Arab University for Security Sciences, 121.

${ }^{41}$ Yusuf al-Qardawi, al-Hal al-Islami Faridah wa Darurah, 23. 229 | al-o8urhan: Kajian Ilmu dan Pengembangan Budaya Al-Qur'an, Vol. 20, No. 2, Desember 2020: 216-249 
Telah menjadi kesepakatan pula bahwa perubahan jiwa atau mental bukanlah perkara mudah, perubahan mental bukanlah seperti mengubah pakaian dengan pakaian lainnya, hakikat perubahan jiwa atau mental adalah perubahan zat manusia itu sendiri, dari satu keadaan kepada keadaan lainnya, yaitu mengubah cara pandangnya, pemikiran-pemikirannya, perasaan-perasaannya, sasaran-sasarannya, dan jalan-jalannya, inilah perubahan revolusioner yang hakiki. ${ }^{42}$ Dikarenakan perubahan tersebut mampu merasuk hingga ke dalam spiritual (ruh) dan substansial atau esensial (jawhar) manusia, yang tidak berhenti pada sisi kulit dan format lahiriah. Perubahan kejiwaan ini tidak akan dapat ditempuh kecuali melalui satu cara pendekatan, yaitu teologis (keimanan). ${ }^{43}$

Sampai di sini pula penulis dapat mengatakan bahwa konsep pendekatan teologis berbasis al-Qur'an ini bila diaplikasikan dengan baik di dalam penanggulangan korupsi bahkan dalam penyakit-penyakit sosial dan kriminal lainnya akan mengurangi perilaku koruptif dan manipulatif yang sering menjadi kendala pembangunan pemerintahan menuju good governance yang selama ini dicita-citakan bersama, ia akan mampu menghadirkan kesejahteraan untuk seluruh elemen bangsa dan rakyat Indonesia, baik pemimpin dan rakyatnya, yakni baldatun tayyibatun wa rabbun ghafūr.

Dapat dikatakan pula bahwa hasil akhir dari konsep ini adalah sebagai suatu tawaran konsep integral, di mana bahwa hanya melalui perbaikan sisi hukum dan aturan yuridis formal saja, yakni dengan meningkatkan jumlah hukuman, dan menaikkan insentif bagi pegawai dan pejabat, dan sangsi sosial, seperti mengisolasi pelaku korupsi dengan menolak untuk dicalonkan sebagai kepala daerah, dan pejabat publik, menolak persaksian mereka di dalam persaksian pengadilan adalah tidak cukup dan tidak efektif sebagai efek jera untuk menanggulangi penyakit korupsi.

Selain itu, konsep "pendekatan teologis" ini adalah konsep yang mengubah manusia melalui "revolusi mental", yang kini tengah ramai diwacanakan oleh pemerintah Indonesia. Di mana konsep ini mampu merasuk dan meresap hingga ke dalam sisi spiritual (ruh) dn esensial manusia itu sendiri, yang tidak hanya berhenti pada sisi kulit dan format lahiriyahnya saja.

\section{Diskursus Seputar Teologi Dan Korupsi}

\section{Teologi Dan Agama}

Secara bahasa kata teologi berasal dari bahasa Greek (Yunani Kuno) yakni dari kata Theologia, istilah ini mengacu kepada Tuhan atau tuhan-tuhan, dan juga berarti suatu ilmu atau studi tentang ketuhanan. ${ }^{44}$ Theologi diartikan juga sebagai: "studi formal tentang dunia ketuhanan dan dasar-dasar kepercayaan keagamaan”, (Formal study of the nature of God and of the foundations of religious belief). ${ }^{45}$

Dalam literatur bahasa Arab istilah ilmu teologi (ilmu ketuhanan) juga dikenal dengan padanan kata dan istilah-istilah lainnya, yakni: ilmu tauhid, ilmu akidah, ilmu ushuluddin, ilmu kalam, ilmu aqa’id, ilmu al-zat wa al-sifat, dan Ilmu al-fiqh al-akbar.

${ }^{42}$ Muhammad Hariyadi and Yusuf Arbi, "Eksposisi Nalar Tafsir Kiai Sholeh Darat; Telaah Transmisi Keilmuan Dan Kontekstualitas Kitab Faidh Ar-Rahman Fi Tarjamah Tafsir Kalam Malik AdDayyan," Al-Burhan: Jurnal Kajian Ilmu Dan Pengembangan Budaya Al-Qur'an 19, no. 1 (2019): 1-30.

${ }^{43}$ Yusuf al-Qardawi, al-Hal al-Islami Faridah wa Darurah, 24.

44 Peter Connolly (ed), Aneka Pendekatan Studi Agama, 313.

${ }^{45}$ A S Hornby, Oxford Advanced Learner's Dictionary Of Current English, 895.

al-@urhan: Kajian Ilmu dan Pengembangan Budaya Al-Qur'an, Vol. 20, No. 2, Desember 2020: 216-249| 230 
Seluruh istilah di atas memiliki makna, pemahaman, pengertian dan substansi yang sama. Akan tetapi istilah ilmu ini lebih populer dengan sebutan ilmu kalam. ${ }^{46}$

Dalam tinjauan bahasa kata-kata akidah berasal dari akar kata "akad",

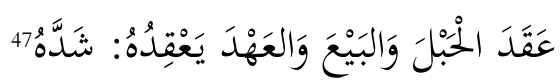

Yakni mengakadkan tali, jual beli, dan janji, yang bermakna: menguatkannya.

Akad berarti sesuatu yang dikuatkan (didirikan) dari berupa bangunan, janji, atau suatu kesepakatan antara dua pihak yang mengharuskan secara konsekuensinya dari masing-masing pihak tersebut melaksanakan sesuatu yang telah disepakatinya, seperti akad jual beli, dan pernikahan. Dan makna kata-kata Akidah adalah suatu hukum/keputusan yang di dalamnya tidak menerima keraguan bagi pemiliknya. Akidah di dalam agama juga bermakna: sesuatu yang di dalamnya dimaksudkan sebagai suatu i'tikad (kepercayaan), bukan sebagai suatu amalan, seperti akidah keberadaan Allah, dan akidah diutusnya para Rasul. ${ }^{48}$

Sementara itu secara pengertian terminologis tentang ilmu teologi/ilmu akidah yang dikemukakan dari para pakar dan ahli di antaranya adalah Menurut Muhammad Abduh pengertian teologi/ilmu tauhid adalah Suatu bidang ilmu yang membahas tentang wujud Allah (keberadaan Allah), dan yang membahas tentang sesuatu (sifatsifat) yang wajib dikukuhkan untuk-Nya, dan yang membahas tentang sesuatu (sifatsifat) yang boleh disifatkan Allah itu dengannya, dan yang membahas tentang sesuatu (sifat-sifat) yang wajib dinafikan (ditiadakan) Allah swt itu dari-Nya, dan juga wajib dinafikan para Rasul itu darinya untuk menetapkan kerasulannya. ${ }^{49}$ Dan ilmu yang membahas tentang sesuatu (sifat-sifat) yang mana para Rasul itu wajib disifati dengannya, dan yang membahas tentang sesuatu (sifat-sifat) yang boleh nisbatkan (disandarkan) kepada mereka, dan juga yang membahas tentang sesuatu (sifat-sifat) yang dilarang dinisbatkan kepada mereka. ${ }^{50}$ Sedangkan menurut al-Buraykan, pengertian ilmu tauhid adalah:

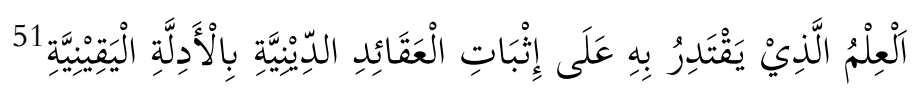

Ilmu yang mana seseorang dengan ilmu tersebut mampu menetapkan akidah-akidah keagamaan dengan dalil-dalil yang meyakinkan.

Menurut Hasan al-Banna pengertian teologi/ilmu akidah adalah:

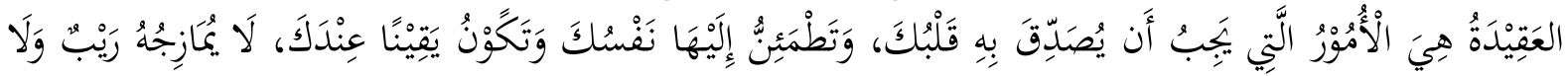

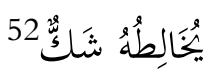

${ }^{46}$ Ibnu Amir al-Haj, tahqiq Jamal Abdun Nasir Abdi al-Mun'im, al-Kamil fi Usuluddin fi Ikhtisar as-Syamil fi Usul ad-Din (Kairo: Dar as-Salam, 1431 H/2010 M), 24.

${ }^{47}$ Abu Ishaq Jamaluddin Ibrahim Ibn 'Ali al-Fairuzabadi, al-Qamus al-Muhit (Beirut Libanon: Dar Ihaya at-Turas al-'Araby, $1422 \mathrm{H} / 2001 \mathrm{M}), 285$.

${ }_{48}^{8}$ Ibrahim Anis, al-Mu'jam al-Wasit, jilid I, 64.

${ }^{49}$ Nur Arfiyah Febriani et al., "GLOBAL CITIZENSHIP EDUCATION IN THE PERSPECTIVE OF QUR ' AN AND," Psychology and Education Journal 57, no. 57 (2020): 5020-29.

${ }^{50}$ Syekh Muhammad 'Abduh, Risalatu at-Tauhid (Kairo: Matba'ah Nahdah Mesir, 1372 H/1956 M), 7 .

${ }^{51}$ Ibrahim Ibn Muhammad al-Buraikan, a-Madkhal Lidarasati al-'Aqidah al-Islamiyyah (Arab Saudi: Dar as-Sunnah, 1918 H/1997 M), 15.

231 | atoßurhan: Kajian Ilmu dan Pengembangan Budaya Al-Qur'an, Vol. 20, No. 2, Desember 2020: 216-249 
Perkara-perkara yang wajib dibenarkan (dipercayai) oleh hati anda, dan jiwa anda harus merasakan ketenangan (kecenderungan) kepadanya, dan perkara-perakara tersebut wajib menjadi keyakinan pada diri anda, di mana ia tidak tercampuri (terkotori) oleh suatu keraguan dan kebimbangan.

Ibrahim Bin Muhammad al-Buraykan (1997) berpandangan definisi teologi/ilmu akidah adalah:

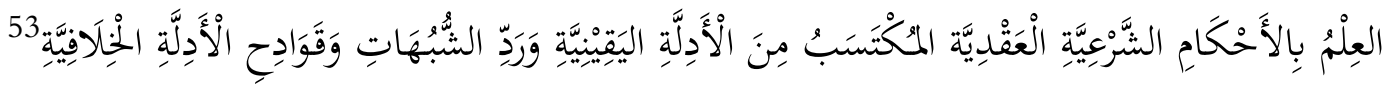

Suatu bidang ilmu tentang hukum-hukum syari'at yang bersifat akidah (kepercayaan) yang dihasilkan (diambil) dari dalil-dalil yang meyakinkan, dan (ilmu tentang) penolakan syubhat-syubhat (kerancuan-kerancuan pemikiran dan keyakinan) dan kecacatan dalil-dalil yang mengandung perselisihan. dalah,

Sementara menurut Imam al-Ghazali (w. 505 H) ilmu kalam/ilmu akidah

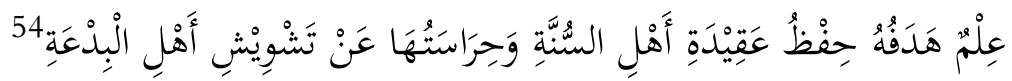

Ilmu yang tujuannya adalah memelihara akidah Ahlus Sunnah, dan membentenginya dari pencemaran Ahli Bid'ah.

Dalam penelitian ini yang dimaksudkan oleh penulis dengan istilah teologi adalah ilmu tauhid, yakni dalam pengertian penulis bermaksud mengaitkan penanggulangan korupsi dengan pendekatan ilmu tauhid berbasis al-Qur'an. Sedangkan istilah agama di dalam bahasa Inggrisnya disebut dengan religion, dan di dalam bahasa Arabnya disebut dengan ad-dīn.

Istilah religion berarti: kepercayaan terhadap keberadaan suatu kekuatan supernatural yang berkuasa, sang pencipta dan pengontrol alam semesta, yang telah memberikan kepada manusia kekuatan spiritual yang akan menjadikannya terus berkelanjutan untuk tetap eksis setelah kematian fisik manusia itu. ${ }^{55}$ (Belief in the existence of supernatural ruling power, the creator and controller of the universe, who has given to a man spiritual nature which continues to exist after the death of the body).

Muhammad Abdullah Darraz menyimpulkan tentang batasan pengertian agama beliau menulis: Kata-kata ad-din yang digunakan di dalam sejarah agamaagama memiliki dua makna saja, dan tidak lebih, yakni, pertama: kondisi kejiwaan ini yang kita namakan dengan sebutan beragama. Kedua: sekumpulan dasar-dasar (prinsip-prinsip) yang dipedomani/dianut oleh suatu komunitas dari komunitaskomunitas (umat-umat) manusia berupa itikad (akidah dan kepercayaan) dan amalan. Makna kedua ini adalah yang lebih mayoritas. ${ }^{56}$

Sedangkan pengertian agama sebagai kesimpulan akhir beliau adalah sebagai berikut: Keyakinan terhadap eksistensi (wujud) dzat atau dzat-dzat ghaib yang Maha tinggi, dzat tersebut memiliki wewenang untuk mengurus dan mengatur urusan yang berkenaan dengan nasib manusia, dan keyakinan yang akan memotivasi manusia untuk bermunajat kepada dzat yang agung itu dengan perasaan cinta maupun takut,

${ }^{52}$ Hasan al-Banna, al-'Aqa'ï,cet I (Beirut Libanon: Dar Al-Qur'an al-karim, 1404 H/ 1984 M), 5.

${ }^{53}$ Ibrahim Ibn Muhammad al-Buraikan, al-Madkhal Lidirasati al-'Aqidah al-Islamiyah, 11.

${ }^{54}$ Abu Hamid al-Ghazali, tahqiq Sa'd Karim al-Faqi, al-Munqiz min ad-Dalal (Iskadariyah: Dar Ibn Khaldun, t.th), 13.

${ }^{55}$ A S Hornby, Oxford Advanced Learner's Dictionary Of Current English, 713.

${ }^{56}$ Muhammad Abdullah Darraz, ad-Din, 28.

al-Burhan. Kajian Ilmu dan Pengembangan Budaya Al-Qur'an, Vol. 20, No. 2, Desember 2020: 216-249| 232 
dan dalam bentuk ketundukan dan pengagungan (peribadatan)". Atau dalam ungkapan singkatnya agama adalah: "Beriman dengan dzat ilahiyah yang pantas dengan ketaatan dan ibadah . ${ }^{57}$ Abul A'la al-Mawdudi menulis: "pengertian agama adalah pedoman kehidupan atau suatu model yang khas untuk berfikir dan beramal yang akan diikuti dan akan dipedomani atas contohnya/idealnya". ${ }^{8}$

\section{Korupsi}

Pengertian korupsi (al-Ikhtilās) secara terminologi sesungguhnya mencakup beberapa istilah-istilah lainnya yang terkait dengannya, yakni al-Fasād (Pengrusakan Harta), ar-Risywah (Suap/Sogok), Dan as-Sariqah (Mencuri). Menurut Ibnu Mandzur (1232 M/630 H) secara pengertian bahasa kata-kata korupsi adalah berasal dari katakata ikhtilās (إختِتالَّ). Beliau menulis:

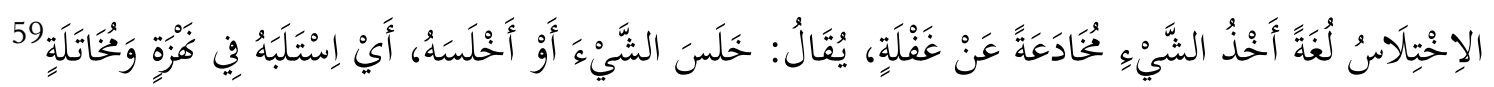

Ikhtilās adalah mengambil sesuatu dengan cara menipu (dan dilakukan) atas dasar kelengahan (dari orang lain), atau mencuri sesuatu, yakni mengambilnya dengan penipuan dan kelengahan.

Al-Fairuzabadi (w. $817 \mathrm{H}$ ) di dalam kamusnya juga menjelaskan bahwa akar kata

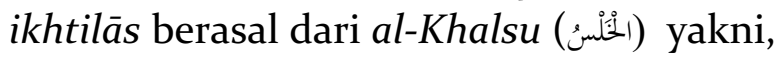

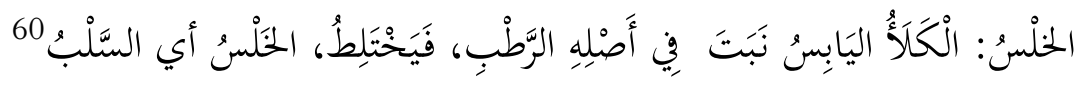

al-Khalsu adalah rumput yang kering yang telah tumbuh pada dasarnya yang basah, kemudian ia bercampur (antara basah dengan kering), al-Khalsu berarti juga merampas.

Sementara menurut as-Sarakhṣī (w. $1097 \mathrm{M} / 490 \quad \mathrm{H}){ }^{61}$ kata-kata korupsi (ikhtilās) secara terminologi adalah:

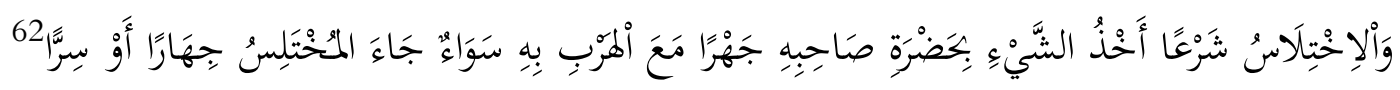

Korupsi adalah mengambil sesuatu di hadapan pemiliknya secara terangterangan, disertai membawa kabur barang yang diambilnya itu, sama halnya apakah pelaku korupsi tersebut melakukannya secara terang-terangan atau sembunyisembunyi.

${ }^{57}$ Muhammad Abdullah Darraz, ad-Din,. 49.

${ }^{58}$ Abul A'la al-Mawdudi, ad-Din al-Qayyim (Jeddah: ad-Dar as-Sa'udiyyah, 1408 H/1988 M), 11.

${ }^{59}$ Abu al-Fadl Jamaluddin Muhamad Ibn Mukaram Ibn Manzur, Lisan al-'Arab (Beirut: Dar alFikr, t.th, jilid VI), 65.

${ }^{60}$ Majduddin Muhammad Ibn Ya'qub al-Fairuzabadi, al-Qamus al-Muhit (Beirut: Dar Ihya atTuras al- 'Arabi, 1422 H/2001 M), 501.

${ }^{61}$ Lihat: Asma' al-'Azawiy Syalqa, "al-Multaqa al-Fiqhiy", dalam www.feqhweb.com. Diakses pada 16 September $2019 \mathrm{M}$.

${ }^{62}$ Syarakhsi, al-Mabsut (Beirut: Dar Al-Ma'rifah, 1978 M, cet.III, jilid IX), 16o; Muhammad Ibn Ahmad ibn Rusyd al-Qurtubi, Bidayatu al-Mujtahid wa Nihayatu al-Muqtasid (Beirut: Dar al-Ma'rifah, cet. VII, jilid II), 436.

233 | at-OBrhan: Kajian Ilmu dan Pengembangan Budaya Al-Qur'an, Vol. 20, No. 2, Desember 2020: 216-249 
Wahbah az-Zuhaylī (w.2015) juga mendefinisikan istilah ikhtila>s (korupsi), beliau menulis,

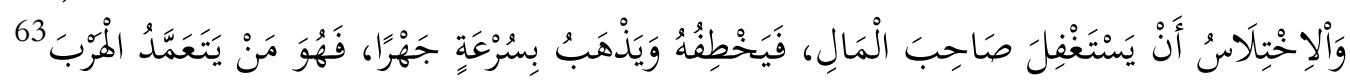

Pengertian istilah korupsi/ikhtilas adalah suatu usaha dari seseorang untuk menjadikan pemilik harta lengah, yang kemudian pelaku tersebut mencurinya, dan pergi dengan cepat secara terang-terangan, dan dia adalah orang yang sengaja untuk kabur".

Berdasarkan penjelasan di atas tentang asal-usul kata ikhtilās, yakni al-Khalsu, seolah-olah mengindikasikan bahwa gambaran pengertian korupsi itu mengandung istilah pengelabuan atau pencampur adukan, yakni mencampurkan antara sesuatu yang kering dengan yang basah. Sebagaimana yang terjadi selama ini, bahwa korupsi juga bermakna memasukan hak orang lain ke dalam hak pribadi, lalu tercampur antara keduanya. Sedangkan istilah al-fasād (pengrusakan harta), sebagaimana yang telah dijelaskan di dalam kamus bahasa Arab pengertian al-fasād berarti,

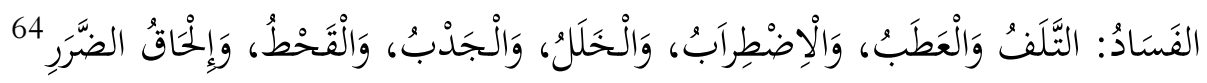

Kerusakan, kegoncangan, kekacauan, kegersangan, kelaparan (musim paceklik) dan mengundang marabahaya. adalah,

Definisi kerusakan (al-fasād) menurut organisasi International Transparency

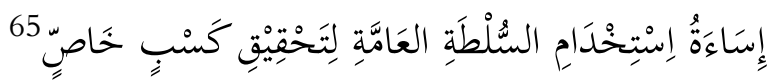

Penyalahgunaan kewenangan publik untuk mendapatkan keuntungan pribadi (khusus).

Istilah al-fasād juga berarti,

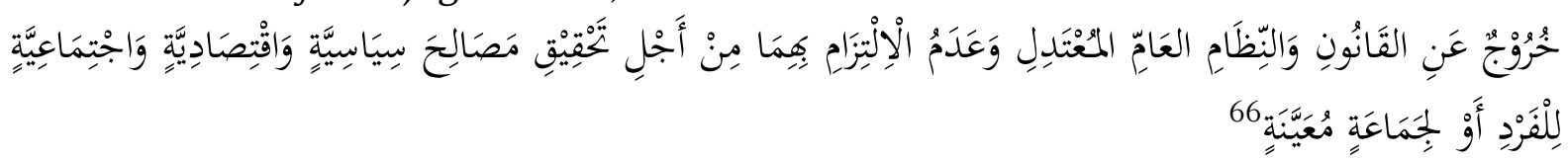

Keluar/menyimpang dari undang-undang dan aturan umum yang cakap/proporsional, dan tidakmengindahkan keduanya karena tujuan mewujudkan kepentingankepentingan politik, ekonomi, dan masyarakat untuk pribadi atau untuk masyarakat tertentu.

Pengertian kerusakan harta juga berarti: "Setiap usaha-usaha finansial dan ekonomi yang bertentangan dengan hukum-hukum dan prinsip-prinsip syariat Islam yang menghantarkan kepada mengkonsumsi harta manusia dengan cara batil, dan

${ }^{63}$ Wahbah az-Zuhayli, al-Fiqh\{ al-Islami wa Adillatuhu (Damaskus: Dar al-Fikr, 1409 M/1989 M, cet III, jilid VI), 93.

${ }^{64}$ Ibrahim Anis, al-Mu'jam al-Wasit, 688.

${ }_{5}$ Ahmad Hamid Muhammad, "al-Fasad al-Maliy Wa al-Idariy Fi Misr", 26, dalam https://nazaha.gov.sa>ar-sa. Diakses pada 14 April 2020.

${ }^{66}$ Ahmad Hamid Muhammad, "al-Fasad al-Maliy Wa al-Idariy Fi Misr", 26, dalam https://nazaha.gov.sa>ar-sa. Diakses pada 14 April 2020.

al-8urhan: Kajian Ilmu dan Pengembangan Budaya Al-Qur'an, Vol. 20, No. 2, Desember 2020: 216-249 | 234 
munculnya distabilitas masyarakat dan kesulitan hidup bagi masyarakat kelas lemah". ${ }^{67}$

Dalam hal ini pula terdapat beberapa ayat-ayat Al-Qur'an yang berbicara tentang perilaku curang, khianat, sogok, suap, penggelapan, dan korupsi, yakni: AyatAyat al-Qur'an yang Berbicara Tentang Penyelewengan Harta Secara Umum dan Korupsi Secara Khusus Adalah: Mencuri: Q.S. al-Māidah/5: 38, penipuan: Q.S. alMutaffifin/83: 1-3, kepemilikan secara tidak sesuai hukum dan Syar'iat: Q.S. an-Nisa/4: 29, khianat terhadap amanah dan kepercayaan: Q.S. al-Anfal/8: 27, kezaliman: Q.S. Taha/20: 111, asy-Syura/42: 40, al-Furqan /25:19, pemufakatan atas kejahatan/ keburukan: Q.S. al-Maidah/5:2, Pembentengan diri dari pengkhianat: Q.S. an-Nisā/4: 105, 107, memenuhi amanah dan janji: Q.S. A>li Imrān/3: 75-77, Q.S. an-Naḥl/16: 91, ingkar janji dan menipu: Q.S. an-Nisā/4: 107-108, saksi palsu: Q.S. al-Hajj/22: 30, pengrusakan dan penipuan terhadap lembaga hukum peradilan dan kehakiman: Q.S. al-Baqarah/2: 188, menyembunyikan kebenaran: Q.S. al-Baqarah/2: 159, 283.

Tabel. II.1

(Ayat-Ayat al-Qur'an Tentang Penyelewengan Harta dan Korupsi secara Umum)

\begin{tabular}{|l|l|}
\hline $\begin{array}{l}\text { Ayat-ayat Al-Qur'an yang berbicara tentang } \\
\text { penyelewengan harta secara umum dan korupsi } \\
\text { secara khusus }\end{array}$ & Surat/Ayat \\
\hline Mencuri & Q.S. al-Māidah/5:38 \\
\hline Penipuan & Q.S. al-Mut\{affifi>>n/83: 1-3 \\
\hline $\begin{array}{l}\text { Kepemilikan secara tidak sesuai hukum dan } \\
\text { syariat }\end{array}$ & Q.S. an-Nisa/4: 29 \\
\hline Khianat terhadap amanah dan kepercayaan & Q.S. al-Anfāl/8: 27 \\
\hline Kedzaliman & $\begin{array}{l}\text { Q.S. Tāhā/20: 111, asy-Syūrā/42: 40, al- } \\
\text { Furqān/25: 19 }\end{array}$ \\
\hline Pemufakatan atas kejahatan/ keburukan & Q.S. al-Māidah/5:2 \\
\hline Pembentengan diri dari pengkhianat & Q.S. an-Nisā/4: 105, 107. \\
\hline Memenuhi amanah dan janji & $\begin{array}{l}\text { Q.S. Āli Imrān/3: 75-77, Q.S. an-Nahl/16: } \\
\text { 91. }\end{array}$ \\
\hline Ingkar janji dan menipu & Q.S. an-Nisā/4: 107-108. \\
\hline Saksi palsu & Q.S. al-Hajj/22: 30. \\
\hline $\begin{array}{l}\text { Pengrusakan dan penipuan terhadap lembaga } \\
\text { hukum peradilan dan kehakiman }\end{array}$ & Q.S. al-Baqarah/2: 188. \\
\hline Menyembunyikan kebenaran & Q.S. al-Baqarah/2: 159, 283. \\
\hline
\end{tabular}

\section{Seputar Rekonstruksi Hukum Korupsi Secara Teologis}

Dalam hal ini rekonstruksi hukum korupsi secara teologis yang penulis ketengahkan adalah mencakup: solusi strategi detektif, preventif dan represif. ${ }^{68}$

${ }^{67}$ Husein Husein Syahattah, "al-Fasād al-Mālīy Asbābuhu, wa Suwaruhu, wa 'Ilājuhu", dalam alwaei.gov.kw. Diakses pada tanggal 31 Maret, 2020.

${ }^{68}$ Strategi detektif adalah dengan cara menguraikan langkah-langkah yang harus dilakukan apabila suatu perbuatan korupsi yang sudah terlanjur dan terjadi, maka semaksimal mungkin korupsi tersebut dapat diindentifikasikan dalam waktu yang sesingkat-singkatnya, sedangkan strategi preventif adalah dengan cara menguraikan langkah-langkah yang harus dilakukan agar semaksimal mungkin dapat mencegah terjadinya korupsi. Sedangkan strategi represif, adalah dengan cara menguraikan langkah-langkah yang harus dilakukan agar perbuatan korupsi yang sudah berhasil diidentifikasi, 235 | at-\$urhan: Kajian Ilmu dan Pengembangan Budaya Al-Qur'an, Vol. 20, No. 2, Desember 2020: 216-249 
Sementara itu solusi strategi detektif dan preventif korupsi menurut perspektif teologis/agama ia adalah mencakup tiga elemen dasar: penguatan akidah, penguatan kalbu, dan penguatan moralitas.

Adapun terkait "solusi strategi represif" korupsi melalui pendekatan teologis pada "aspek peraturan perundang-undangan yang bersifat monopolistik" maka ia dilakukan dengan cara mereformasi atau memperbaiki perundang-undangan yang bersifat monopolistik tersebut yang telah menjadi akar sebab permasalahan korupsi ${ }^{69}$, yaitu melalui reformasi/perbaikan pada empat strategi pendekatan teologis berikut ini: penguatan lembaga pengawasan (lembaga al- $H\{$ isbah), penguatan hukum yuridis dan dunia peradilan, penguatan masyarakat dan penguatan aspek religiusitas. Sedangkan terkait dengan prinsip-prinsip tatanan hukum dan peradilan menurut AlQur'an, ia mencakup: tatanan ketuhanan (ad-Dustūr al-Ilāhī/ar-Rabbāniyyah), kemanusiaan (al-Insāniyah), persamaan (al-musāwāt/equality before the law), keadilan (al-'dālah/justice), musyawarah (asy-syūrā), menghormati kebebasan (ih\{tirāmu al$h\{$ urriyyāt $) .^{70}$

Di dalam pembahasan ini penulis juga berpandangan adanya relevansi antara teologi dan ibadah dengan pencegahan korupsi dan kerusakan tata kelola harta dan manajemen, yang mencakup : 1. Relevansi logis antara iman dan aktivitas. 2. Perilaku korupsi, manipulasi, penyimpangan hukum, kejahatan sosial dan kerusakan tata kelola harta dan manajemen adalah ibarat "kalimat khabithah" yang bersifat hanya sementara waktu.

Sedangkan relevansi antara teologi dan ibadah dengan pembangunan peradaban masyarakat muslim adalah mencakup: terciptanya keamanan dan stabilitas politik 71, terciptanya kenyamanan dan kenikmatan kehidupan, menunjukkan kepada kebenaran (al-Haq), melimpahnya rezeki, terpeliharanya ketahanan negara dari musuh $\mathbf{7 2}$, Terwujudnya Pertolongan dan Kemenangan ${ }^{73}$,

semaksimal mungkin dapat diproses menurut ketentuan hukum secara cepat, tepat, dan tingkat kepastian hukum yang tinggi.

${ }^{69}$ Sebagaimana penjelasan Srinita (2016), ia menyimpulkan bahwa faktor-faktor penyebab korupsi adalah: aspek perilaku individu, organisasi, masyarakat, dan peraturan perundang-undangan yang bersifat monopolistik. Lihat: Srinita, "Strategi Menihilkan Korupsi di Sektor Pendidikan dan Kesehatan”, Jurnal Kajian Politik Dan Masalah Pembangunan 12, no. 2 (2016): 1898.

${ }^{70}$ Bandingkan Attamimi, Munif Mahadi, and Muhammad Hariyadi. "Al-Qur'an Menjawab Tantangan Hak Asasi Manusia." Al-Burhan| Jurnal Kajian Ilmu dan Pengembangan Budaya AlQur'an 20.1 (2020): 50-77. Aziz, Abd, and Saihu Saihu. "Interpretasi Humanistik Kebahasaan: Upaya Kontekstualisasi Kaidah Bahasa Arab." Arabiyatuna: Jurnal Bahasa Arab 3.2 (2019): 299-214.

${ }^{71}$ Di antara ayat-ayat Al-Qur'an yang berbicara tentang jaminan keamanan, dan kehidupan yang baik dan tenteram, sejahtera dan sentosa dari Allah baik di dunia dan di akhirat bagi orang-orang yang beriman dan bertakwa, di mana bagian dari beriman dan bertakwa adalah memelihara amanahNya dan menegakkan aturan-aturan-Nya di muka bumi adalah: Q.S. an-Nahl/16: 97, Q.S. al-'Ashr/103: 12, Q.S. al-Baqarah/2: 25, Q.S. al-'An’ām/6: 48, Q.S. Yūnus/10: 64, Q.S. al-Kahfi/18: 30-31, Q.S. al$\mathrm{H}\{$ adid/57: 12, 28.

${ }_{72} \mathrm{Di}$ antara ayat-ayat Al-Qur'an yang berbicara tentang jaminan Allah atas orang-orang beriman tentang stabilitas politik dari musuh adalah: Q.S. al-H\{ajj: 38, Q.S. al-Anbiya: 87-88, Q.S. Ali Imran/3: 120.

${ }^{73} \mathrm{Di}$ antara ayat-ayat al-Qur'an yang berbicara tentang jaminan Allah atas orang-orang beriman bahwa mereka akan diberikan pertolongan dan kemenangan adalah: Q.S. al-Baqarah/2: 194, Q.S. Ali Imran/3: 76, dan 120, Q.S. at-Talāq/65: 2-3, 4, Q.S. Țāha/20: 46, Q.S. al-Ḥadīd/57: 4, Q.S. an-Nisa/4: 108. aloBurhan. Kajian Ilmu dan Pengembangan Budaya Al-Qur'an, Vol. 20, No. 2, Desember 2020: 216-249| 236 


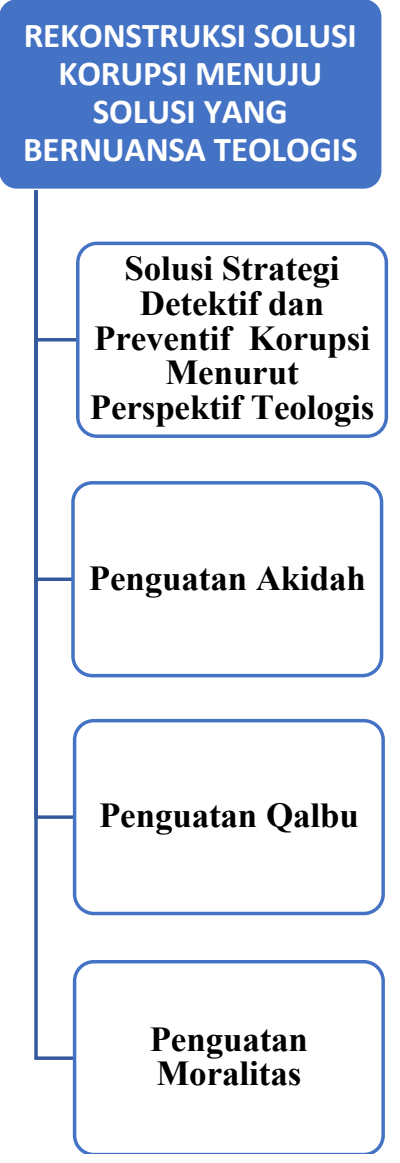

Tabel. 1.3

Pada gambar tabel di atas (Tabel. 1.3) terlihat bahwa rekonstruksi solusi strategi detektif dan preventif korupsi menurut perspektif teologis mencakup tiga hal, yakni penguatan akidah, penguatan kalbu, dan penguatan moralitas. 


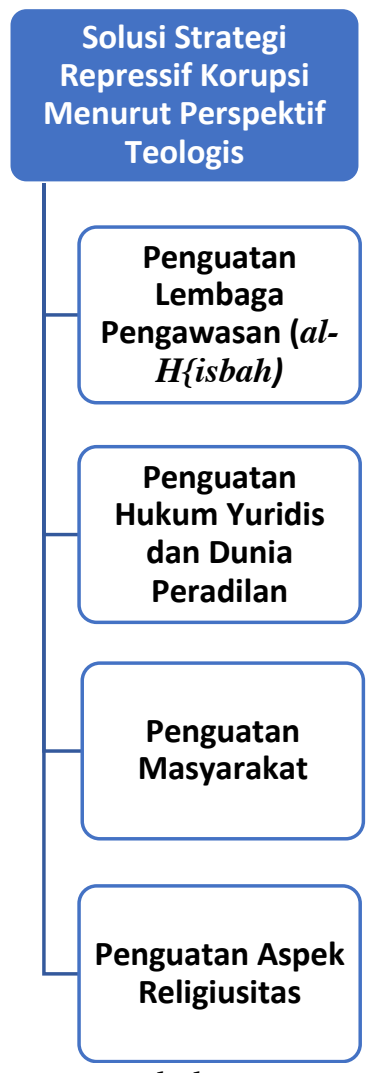

Tabel. 2.3

(Tabel Solusi Strategi Represif Korupsi Menurut Perspektif Teologis)

Pada gambar tabel di atas (tabel. 2.3) terlihat bahwa solusi strategi represif korupsi menurut perspektif teologis mencakup empat hal, yakni penguatan lembaga pengawasan (al-hisbah), penguatan hukum yuridis dan dunia peradilan, penguatan masyarakat, dan penguatan aspek religiositas. 


\section{Relevansi Antara Teologi dan Ibadah Dengan Pencegahan Korupsi dan Kerusakan Tata Kelola Harta Dan Menejemen:}

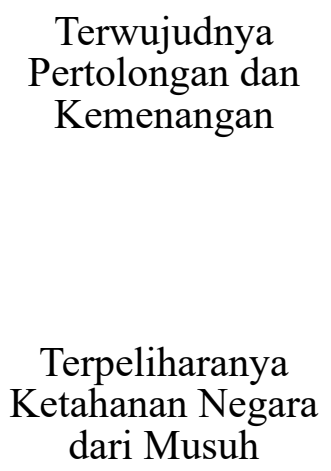
Pertolongan dan Kemenangan
Terpeliharanya dari Musuh

Terciptanya

Keamanan dan

Stabilitas Politik

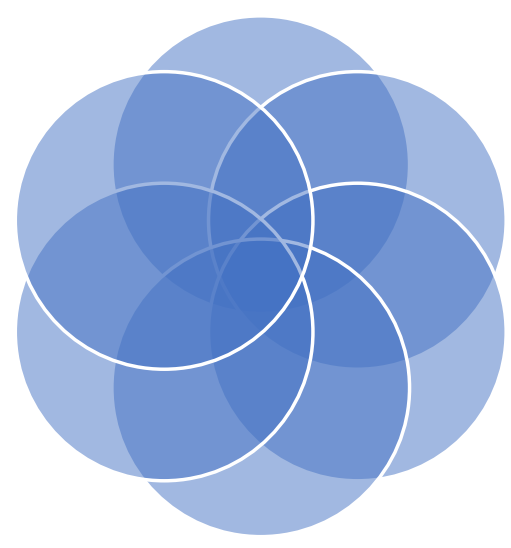

Terciptanya

Kenyamanan dan

Kenikmatan

Kehidupan

Menunjukkan

Kepada Kebenaran (al-Haq)

\section{Melimpahnya Rezeki}

Tabel 3.3.

(Tabel relevansi antara teologi dan ibadah dengan pencegahan korupsi dan kerusakan tata kelola harta dan manajemen).

Tabel 3.3 di atas menggambarkan bahwa relevansi antara teologi dan ibadah dengan pencegahan korupsi dan kerusakan tata kelola harta dan manajemen adalah terciptanya baldatun tayyibatun wa rabbun ghafūr yang meliputi: terciptanya keamanan dan stabilitas politik, terciptanya kenyamanan dan kenikmatan kehidupan, menunjukkan kepada kebenaran (al-haq), melimpahnya rezeki, terpeliharanya ketahanan negara dari musuh, dan terwujudnya pertolongan dan kemenangan.

Mengenai solusi strategi detektif, preventif, dan represif secara keseluruhan terhadap korupsi melalui penguatan basis-basis teologis/agama, maka dalam hal ini beberapa cara yang diketengahkan oleh penulis untuk penguatan basis-basis teologis, yang secara dinamis cara-cara penguatan basis-basis teologis tersebut sangat berfungsi untuk solusi strategi detektif, preventif, dan represif bagi penanggulangan korupsi, yakni: Bertafakur Tentang Tanda-Tanda Kebesaran Tuhan dan Ciptaan-Nya ${ }^{74}$,

${ }^{74}$ Di dalam perspektif al-Qur'an makna dan pengertian dari istilah "ayat" memiliki enam dimensi pengertian, yakni berarti: 1. Tanda-tanda (al'alāmāt) seperti pada Q.S. ar-Ru>m /30: 20, asySyu'ara/26>: 128, dan al-An'ām/6: 158.

2. Bermakna Al-Qur'an, seperti pada Q.S. Āli Imrān/3: 7, az-Zumar/39: 71, dan an-Nahl/16: 101.

3. Bermakna mukjizat, seperti pada Q.S. al-Qhas\}as/28: 36, dan al-Qamar/54: 2.

4. Bermakna pelajaran (al-'Ibrah), seperti pada Q.S. Maryam/19: 21. 
Mengenal Allah swt Dengan Mempelajari Nama-Nama dan Sifat-Sifat- Nya (Ma'rifatullāh), Berdakwah: Amar Ma'ruf dan Nahi Munkar, Mempelajari Ilmu-Ilmu berbasis al-qur'an dan as-sunnah, mengamalkan ibadah-ibadah sunnah, mempelajari biografi rasulullah (sìrah nabawiyah) dan keluhuran budi pekertinya, mempelajari alqur'an dan mentadaburinya, memperbanyak berzikir dan berdoa, dan kesadaran tentang hukum koruptor dalam agama. ${ }^{75}$

5. Bermakna al-Kita>b, seperti pada Q.S. al-Jāthiyah/45: 8, dan Q.S. al-Mu'minūn/23: 66.

6. Bermakna larangan dan perintah (al-Amru wa an-Nahyu), seperti pada Q.S. al-Baqarah/2: 242. Lihat: Husain bin Muhammd ad-Damaghani, Qāmūs al-Qur'ān (Is $\{l a ̄ h\{$ al-Wujūh wa an-Nazā'ir fí al-Qur'ān al-Karìm), hal. 60.

75 Muhammad Hariyadi, "METODOLOGI TAFSIR AL-QUR'AN KONTEMPORER SALAM PENDEKATAN ILMU KOMUNIKASI MODERN," Jurnal Statement 11, no. 1 (2021): 30-40.

al-\$urhan: Kajian Ilmu dan Pengembangan Budaya Al-Qur'an, Vol. 20, No. 2, Desember 2020: 216-249| 240 


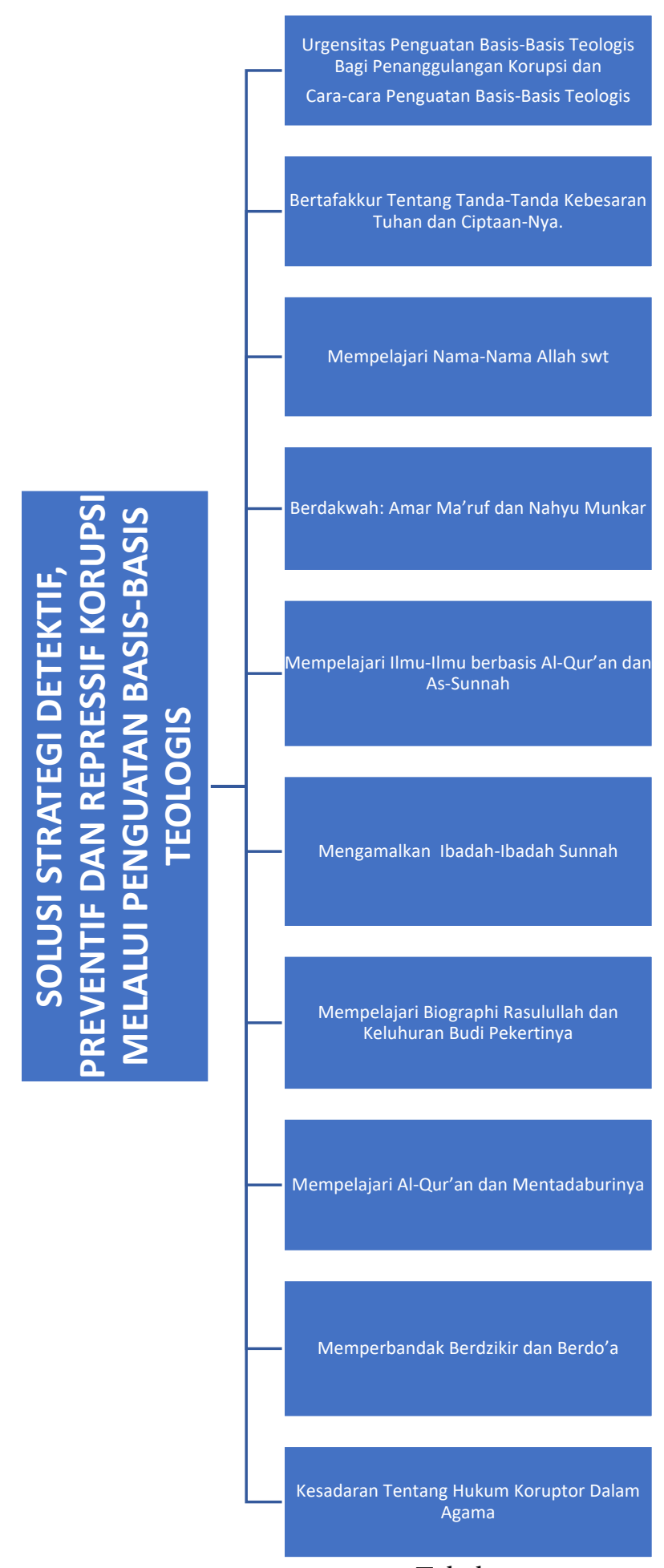

Tabel.4.1

Tabel ini (Tabel.4.1) menggambarkan solusi strategi detektif, preventif, dan represif secara keseluruhan terhadap korupsi melalui penguatan basis-basis teologis/agama adalah mencakup point-point: Bertafakkur Tentang Tanda-Tanda Kebesaran Tuhan dan Ciptaan-Nya, Mengenal Allah swt Dengan Mempelajari NamaNama dan Sifat-Sifat- Nya (Ma'rifatullāh), Berdakwah: Amar Ma'ruf dan Nahi Munkar, Mempelajari Ilmu-Ilmu Berbasis al-Qur'an dan as-Sunnah, Mengamalkan IbadahIbadah Sunnah, Mempelajari Biografi Rasulullah (Sïrah Nabawiyah) dan Keluhuran 
Budi Pekertinya, Mempelajari al-Qur'an dan Mentadaburinya, Memperbanyak Berdzikir dan Berdo'a, dan Kesadaran Tentang Hukum Koruptor dalam Agama.

Sementara itu berkaitan dengan solusi strategi detektif, preventif, dan represif korupsi melalui penguatan basis-basis teologis menurut hemat penulis adalah mencakup dua hal pokok, yakni, rambu-rambu al-Qur'an tentang pengelolaan harta, negara, dan manajemen untuk membentengi diri dari korupsi dan urgensitas penguatan nilai-nilai teologis dalam pencegahan korupsi pada individu dan masyarakat. ${ }^{76}$

Adapun rambu-rambu al-Qur'an tentang pengelolaan harta, negara, dan manajemen untuk membentengi diri dari korupsi adalah meliputi pokok-pokok berikut: amanah (Trust), benar (Transparency), dan menepati janji (faithfulness). Sedangkan urgensitas penguatan nilai-nilai teologis dalam pencegahan korupsi pada individu dan masyarakat adalah mencakup pokok-pokok berikut: beriman Kepada Allah swt dan Urgensitasnya Terhadap Pencegahan Kejahatan Korupsi, beriman kepada Malaikat dan Urgensitasnya Terhadap Perbaikan Moralitas dan Pencegahan Penyakit Korupsi, Beriman kepada Hari Akhir dan Urgensitasnya Terhadap Pencegahan Kejahatan Korupsi, Iman kepada Qada dan Qadar-Nya dan Urgensitasnya Terhadap Perbaikan Moralitas dan Pencegahan Kejahatan Korupsi.

${ }^{6}$ Alijaya, Adudin, and Muhammad Hariyadi. "Argumen Al-Qur'an Tentang Paradigma Ekopedagogi." Al-Burhan| Jurnal Kajian Ilmu dan Pengembangan Budaya Al-Qur'an 19.2 (2019). 


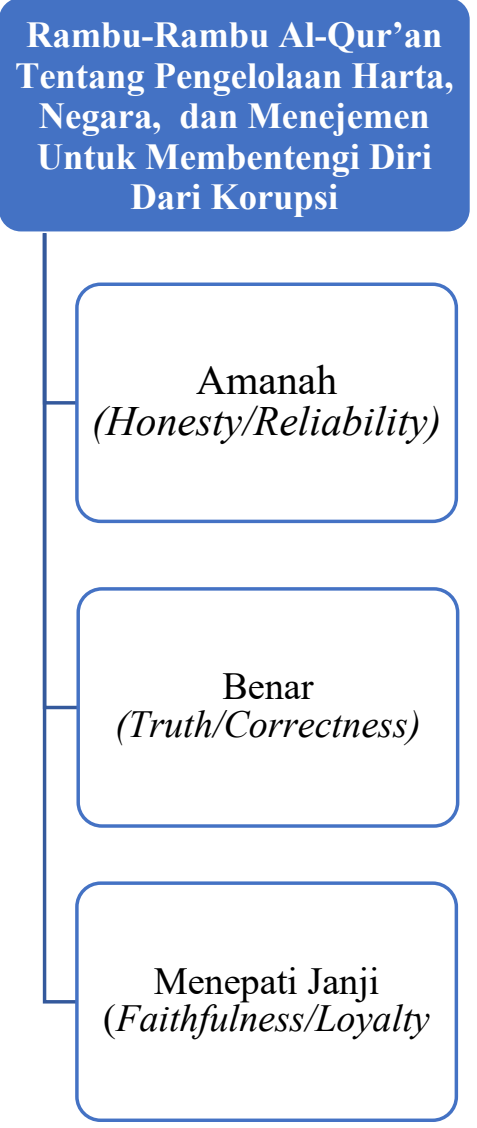

Tabel 5.1

(Rambu-rambu Al-Qur'an tentang pengelolaan harta, negara, dan manajemen untuk membentengi diri dari korupsi)

Hubungan hierarki pada gambar tabel di atas (tabel 5.1) menggambarkan tentang hubungan keterkaitan yang kuat, yakni berkomitmen di dalam mengikuti rambu-rambu al-Qur'an tentang pengelolaan harta, negara, dan manajemen yang mencakup: amanah (honesty/reliability), benar (truth/ correctness), dan menepati janji (faithfulness/loyalty) adalah syarat-syarat yang mesti dipenuhi dalam upaya membentengi diri dari korupsi pada individu dan masyarakat, di mana buah akhirnya adalah terciptanya baldatun țayyibatun wa rabbun ghafūr. 


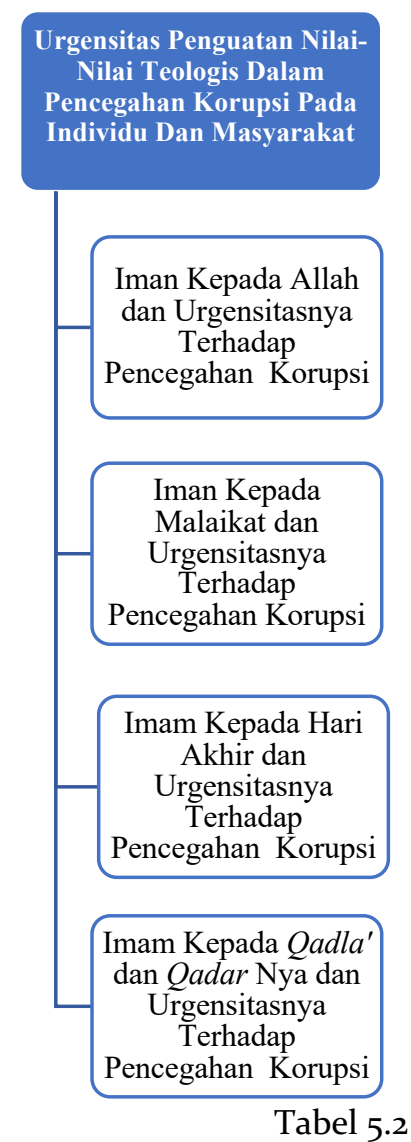

(Tabel cara-cara penguatan basis-basis teologis dan agama sebagai solusi strategi detektif, preventif, dan represif korupsi)

Tabel 5.2 menggambarkan bahwa keimanan itu memiliki cara-cara penguatan dan penumbuhan-nya yang wajib diambil dan diupayakan dalam upaya mengatasi berbagai penyakit sosial, dan antaranya adalah korupsi. Di antara cara-cara penguatan basis-basis teologis dan agama yang harus diambil untuk kemudian diletakkan sebagai "solusi strategi detektif, preventif, dan represif korupsi" adalah point-point ini: beriman Kepada Allah Swt, beriman kepada Malaikat, beriman kepada hari akhir, dan beriman kepada qadla' dan qadar Nya.

\section{Kesimpulan}

Penanggulangan korupsi dengan pendekatan konvensional yang non-teologis mengalami kebuntuan, yang disebabkan oleh krisis moral, identitas, dan situasi sosial, dan propaganda kelompok yang mengutamakan strategi penanggulangan korupsi dengan pendekatan perbaikan aturan perundang-undangan daripada pendekatan teologis. Pendekatan konvensional yang non-teologis tersebut selama ini ternyata tidak efektif, sebab ia hanya bersifat exterior superficial (sațiyyun wa zāhiriyyun), bukan solusi yang mendalam, yaitu solusi yang mencapai hingga masuk ke kedalaman substansi permasalahan, yakni pendekatan teologi atau agama.

Perspektif al-Qur'an dalam penanggulangan korupsi ditemukan melalui tiga strategi, yaitu: detektif, preventif, dan represif. Strategi detektif dan preventif ditempuh melalui tiga cara: penguatan akidah, penguatan kalbu, dan penguatan moralitas. Sedangkan strategi represif ditempuh melalui empat cara: penguatan lembaga pengawasan (al-hisbah), penguatan hukum yuridis dan dunia peradilan, atőurhan: Kajian Ilmu dan Pengembangan Budaya Al-Qur'an, Vol. 20, No. 2, Desember 2020: 216-249 | 244 
penguatan masyarakat, dan penguatan aspek religiositas. Sementara strategi detektif, preventif, dan represif secara keseluruhan ditempuh melalui cara penguatan basisbasis dan nilai-nilai teologis.

Hal menarik lain yang ditemukan di dalam penelitian ini adalah, bahwa intervensi pendekatan teologis yang dideskripsikan Al-Qur'an di dalam penanggulangan korupsi dapat mewujudkan pembangunan peradaban masyarakat Muslim (baldatun tayyibatun wa rabbun ghafür), yakni: terciptanya keamanan dan stabilitas politik, terciptanya kenyamanan dan kenikmatan kehidupan beragama dan bernegara.

Asas perbaikan dan reformasi sosial masyarakat muslim (revolusi mental) yang dianut dalam perspektif teologis adalah: perbaikan dan reformasi sosial masyarakat muslim itu tidak akan pernah dapat dibangun atau diwujudkan hanya dengan melalui perbaikan aturan undang-undang dan hukum (tashri') saja, akan tetapi terlebih dahulu harus melalui dua media pendekatan, yakni pertama adalah: dakwah dan penyadaran (teologis), kemudian kedua: pendidikan dan pengajaran. Hal tersebut dilakukan sebelum perbaikan aturan hukum dan perundang-undangan. Solusi utama teologis dalam upaya penanggulangan korupsi adalah melalui dua pendekatan teologis yakni: pelurusan cara pandang dalam memandang nilai kehidupan dunia berdasarkan parameter akidah Islam (Tashīh al-Qiyam Bimīzān Hāzihi al-'Aqīdah), dan Tazkiyatu an-Nafs (Penyucian Jiwa). Ilmu teologi Islam adalah ilmu termulia dan ilmu pertama yang wajib dipelajari oleh setiap muslim, sebab ia adalah dakwah pertama para rasulrasul Allah swt, sebagai asas agama, fondasi dan jaminan keberlangsungan kehidupan, dan pengangkat amalan manusia ke langit.

Pengertian korupsi adalah sebuah penyalahgunaan kekuasaan atau wewenang seorang pejabat publik/pegawai negara, dengan usaha penyuapan atau penyogokan, dengan niat untuk memperoleh keuntungan pribadi, keluarga dekat, atau kelompok, dengan melanggar aturan pelaksanaan, dan merugikan perekonomian negara dan kepentingan umum, dan kejahatan korupsi secara perspektif teologis hanya dapat diredam dan diminimalisir melalui suatu upaya terpadu yang bersifat holistik dan teologis, yakni melalui peningkatan dan penguatan basis teologis pada diri setiap orang beriman, terutama para abdi negara atau ASN (Aparatur Sipil Negara) khususnya, dan masyarakat luas pada umumnya.

Kejahatan korupsi di dalam perspektif hukum positif adalah termasuk ke dalam kategori atau pengertian khianat. Pengertian khianat yang dimaksudkan di sini adalah sebagaimana perilaku khianat yang selama ini dipahami di dalam perspektif Fiqh Islam. Oleh karenanya dampak hukum dan konsekuensi pada perilaku korupsi adalah sama seperti dampak hukum dan konsekuensi pada perilaku khianat. Mayoritas para ahli Fiqh Islam (fuqahā) berpandangan: Istilah korupsi adalah berbeda dengan istilah mencuri, karena itu tidak ada hukum potong tangan atas pelaku korupsi. Dalam hal ini hukuman yang berlaku atas koruptor adalah hukuman ta'zīr, seperti pukulan, ancaman, dan hukuman penjara yang lama, dan dihukum dengan cara diambil harta mereka.

Agama Islam telah mengharamkan praktik korupsi, pemberian gratifikasi/hadiah, penyuapan, dan penyogokan terhadap pejabat, pemimpin, pegawai publik dan negara, dan pembantu-pembantu mereka, juga mengharamkannya atas mereka untuk menerimanya jika hal-hal itu ditawarkan kepada mereka, dan agama Islam juga telah memberikan peringatan keras kepada orang lain yang menjadi 245 | al-\$urhan: Kajian Ilmu dan Pengembangan Budaya Al-Qur'an, Vol. 20, No. 2, Desember 2020: 216-249 
mediator antara penyuap dan yang disuap. Nash-nash kitab suci, baik al-Qur'an, Injil (Perjanjian Baru), dan Taurat (Perjanjian Lama) banyak membicarakan bahaya korupsi atau sogok menyogok/suap- menyuap (rishwah) dan ancamannya serta dampak buruknya terhadap bangunan perundang-undangan dan peradilan. Di mana korupsi dan sogok-menyogok adalah faktor terpenting dan utama yang dapat menyelewengkan hukum peradilan itu dari tujuan utamanya.

Dalam perspektif teologis sesuatu yang melatarbelakangi seseorang itu melakukan korupsi adalah karena faktor kotornya kalbu, dan kelemahan manusia itu sendiri secara keimanan, yang kemudian melahirkan sifat serakah, tamak, dan rakus di dalam jiwa dan kalbunya, dan ketidaksabarannya di dalam menghadapi godaan harta, jabatan, dan kedudukan dunia. Korupsi adalah tergolong dosa besar, dan pelakunya mendapatkan ancaman di akhirat, dan ia akan memikul harta korupsinya pada hari Kiamat. Korupsi adalah indikator lemah dan kurangnya keimanan, dan korupsi adalah karakter orang munafik. Rambu-rambu al-Qur'an terpenting tentang pengelolaan manajemen, harta, dan negara untuk membentengi diri dari korupsi di antaranya: amanah (trust/honesty/integrity/good faith/reliability), dan benar (transparency/ truth /sincerity/correctness.

Orang-orang yang terpapar korupsi adalah mereka yang sedang mengalami penurunan dan pelemahan keimanan. Demikian sebab secara teologis keimanan itu selalu mengalami fluktuasi, yakni mengalami penurunan dan peningkatan. Penurunan dan pelemahan keimanan adalah karena disebabkan faktor maksiat yang dilakukan oleh seseorang. Sedangkan peningkatan dan penguatan keimanan adalah karena disebabkan faktor ketaatan dan kepatuhan yang dilakukan oleh seorang hamba muslim tersebut.

Cara-cara peningkatan dan penguatan basis-basis teologis yang menjadi benteng terkuat bagi pencegahan dari kejahatan korupsi adalah meliputi beberapa aspek penting yaitu: bertafakkur tentang tanda-tanda kebesaran Tuhan dan ciptaanNya, mengenal Allah swt dengan mempelajari nama-nama dan sifat-sifat- Nya (ma'rifatullāh), berdakwah: amar ma'ruf dan nahyu munkar, mempelajari ilmu-ilmu berbasis al-Qur'an dan as-sunnah, mengamalkan ibadah-ibadah sunnah setelah ibadah-ibadah fardlu, mempelajari biografi Rasulullah (sirah nabawiyah) dan keluhuran budi pekertinya, mempelajari al-Qur'an dan mentadaburinya, memperbanyak berdzikir dan berdo'a, dan kesadaran tentang hukum koruptor dalam agama.

Penguatan nilai-nilai teologis dalam pencegahan kejahatan korupsi dapat ditempuh dan diupayakan cara-cara berikut ini, yakni: beriman kepada Allah sw, beriman kepada malaikat, beriman kepada hari akhir, dan beriman kepada qadla' dan qadar -Nya.

Penelitian ini memiliki kesamaan pandangan dengan Muhammad Tahir Ibnu Asyur (w.1973 M), Hasan al-Banna (w.1949 M), Sayid Abu al -Hasan Ali al-Hasani anNadwi. (w.1999 M), Syekh Muhammad al-Ghazali (W.1987 M), Yusuf al-Qardlawi (1974 M), Tariq bin Sulaiman al-Bahlal (1425 H), Aziz Syamsuddin (2011 M), Srinita (2016 M), Susan Rose Ackerman (1992 M), Syed Husein Alatas (1982 M), M. Darwis Hude (2017 M), dan Nur Arfiyah Febriani (2014 M) yang menyatakan strategi yang lebih berperan dan vital di dalam memberantas korupsi adalah melakukan revolusi moral/mental (morality revolution), yang harus dimulai dari diri sendiri, kemudian lingkungan keluarga, lingkungan masyarakat, dan lingkungan negara dari mulai aloßurhan: Kajian Ilmu dan Pengembangan Budaya Al-Qur'an, Vol. 20, No. 2, Desember 2020: 216-249 | 246 
pegawai biasa sampai pejabat penting, kemudian setelah itu adalah perbaikan dan perubahan struktural dan legal dalam administrasi pemerintahan.

Temuan dalam penelitian ini sebaliknya berbeda dengan pendapat: Jack Bologne (2006), Robert Klitgaard (1988), Ramirez Torres, dan Abraham Maslow (w.1970), dan Victor Harold Vroom (1.1932) yang menyatakan dan mengedepankan paradigma kering teologis di dalam memandang faktor-faktor yang melatarbelakangi timbulnya praktik korupsi. 


\section{Daftara Pustaka}

'Abduh, Syekh Muh\{ammad Risalatu at-Tauhid. Kairo: Matba'ah Nahdah Mesir, 1372 $\mathrm{H} / 1956 \mathrm{M}$.

Ad-Dimasyqi, 'Imaduddin Abi al Fidā’ Isma'il Ibn Kasir al-Qurasyi (Imam Ibnu Katsir), Tafsir al-Qur'an al-Azim. Damaskus: Maktbah Dar al- Faiha, 1414 H/1994 M.

Al-Bahlal, Tariq Ibn Sulaiman "Al-Iman wa Dawruhu fi al-Wiqayah min al-Jarimah", Naif Arab University for Security Sciences (1425 H): 104.

Al-Banna, Hasan aal-'Aqa’id,cet I. Beirut Libanon: Dar Al-Qur'an al-karim, 1404 H/ $1984 \mathrm{M}$.

Al-Buraikan, Ibrahim Ibn Muhammad a-Madkhal Lidarasati al-'Aqidah al-Islamiyyah. Arab Saudi: Dar as-Sunnah, 1918 H/1997 M.

Al-Fairuzabadi, Abu Ishaq Jamaluddin Ibrahim Ibn 'Ali al-Qamus al-Muhit. Beirut Libanon: Dar Ihaya at-Turas al-'Araby, 1422 H/2001 M.

Al-Fawzan Saleh Ibn Fawzan Ibn Abdullah, al-Irsyad Ila Shahih al-I'tiqad. Jeddah: Dar Ibnu al-Jauziy, $1421 \mathrm{H}$.

Al-Ghazali, Abu Hamid tahqiq Sa'd Karim al-Faqi, al-Munqiz min ad-Dalal. Iskadariyah: Dar Ibn Khaldun, t.th.

Al-Haj Ibnu Amir, tahqiq Jamal Abdun Nasir Abdi al-Mun'im, al-Kamil fi Usuluddin fi Ikhtisar as-Syamil fi Usul ad-Din. Kairo: Dar as-Salam, 1431 H/2010 M.

Al-Hanafi, Lihat: 'Allamah Sadruddin 'Ali Ibn Ali Muhammad Ibn Abi al-Izz tahqiq Ahmad Muhammad Syakir, Syarah al-'Aqidah at-Tahawiyah. Peshawar: Kutub Khānah Rasyīdiyyah, 1413 H/1993 M.

Al-Qardawi Yusuf a, al-'Ibadah Fi al-Islām. Beirut: Mu'assasah ar-Risalah, 1399 M/ 1979 M.

. Malāmih al-Mujtama' al-Muslim Allazi Nunsyiduhu. Beirut: Mu'assasah arRisalah, $2001 \mathrm{M} / 1422 \mathrm{H}$.

. al-Hal al-Islami Faridah wa Darurah. Beirut: Muassasah ar-Risalah, 1394 H/1974 M.

Al-Mawdudi, Abul A'la ad-Din al-Qayyim. Jeddah: ad-Dar as-Sa'udiyyah, 1408 H/1988 M.

Al-Zuhayli, Wahbah al-Fiqh\{ al-Islami wa Adillatuhu. Damaskus: Dar al-Fikr, 1409 $\mathrm{M} / 1989 \mathrm{M}$.

Alijaya, Adudin, and Muhammad Hariyadi. "Argumen Al-Qur'an Tentang Paradigma Ekopedagogi." Al-Burhan| Jurnal Kajian Ilmu dan Pengembangan Budaya AlQur'an 19.2 (2019).

Asyur, Muhammad Tahir Ibnu. an-Nizāam al-Ijtimā’i fi al-Islām. Kairo: Dar as-Salam, $1431 \mathrm{H} / 2010 \mathrm{M}$.

Aziz, Abd , Sastra dan Etika. Studi Etika Sosial atas Diwan 'Abd al-Qadir al-Jilani), (Tangerang Selatan: Yapin An-Namiyah, 2021.

Azra, Azyumardi, “Korupsi Dalam Perspektif Good Governance, Jurnal Kriminologi Indonesia 2, no. 1 (2002): 31.

Attamimi, Munif Mahadi, and Muhammad Hariyadi. "Al-Qur' an Answering the

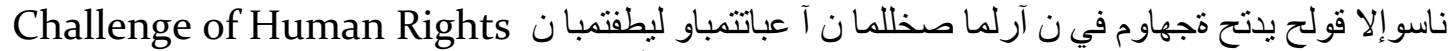

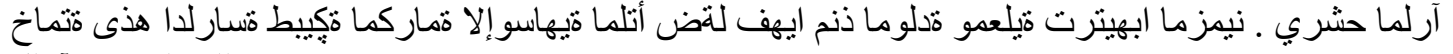
ض.d., 50-79. 
Febriani, Nur Arfiyah, Badru Tamam, M Darwis Hude, Hamdani Anwar, and Muhammad Suaib Tahir. "GLOBAL CITIZENSHIP EDUCATION IN THE PERSPECTIVE OF QUR ' AN AND.” Psychology and Education Journal 57, no. 57 (2020): 5020-29.

Hariyadi, Muhammad. "METODOLOGI TAFSIR AL-QUR'AN KONTEMPORER SALAM PENDEKATAN ILMU KOMUNIKASI MODERN.” Jurnal Statement 11, no. 1 (2021): 30-40.

Hariyadi, Muhammad, and Yusuf Arbi. "Eksposisi Nalar Tafsir Kiai Sholeh Darat; Telaah Transmisi Keilmuan Dan Kontekstualitas Kitab Faidh Ar-Rahman Fi Tarjamah Tafsir Kalam Malik Ad-Dayyan.” Al-Burhan: Jurnal Kajian Ilmu Dan Pengembangan Budaya Al-Qur'an 19, no. 1 (2019): 1-30.

Hude, M. Darwis Logika al-Qur'an: Pemaknaan Ayat Dalam Berbagai Tema, editor. Abd. Muid, N. Jakarta: Penerbit Eurabia, PT. Nagakusuma Media Kreatif, 2017.

Parris, Robert Klitgaard, Ronald Maclean Abaroa, H. Lindsey Corrupt Cities: a practical Guide to cure and prevention. California: ICS Press, 2000.

Qutub Sayid, Fi Zilāli Al-Qur'ān. Kairo: Dar asy-Syuruq, t.th.

Manzur, Abu al-Fadl Jamaluddin Muhamad Ibn Mukaram Ibn Lisan al-'Arab. Beirut: Dar al-Fikr, t.th.

Mubin, Fatkhul, and Abd Aziz. "Politik Pendidikan Islam Indonesia: Perlawanan Pesantren Terhadap Hegemoni Pendidikan Barat Era Kolonialisme Belanda." Al Amin: Jurnal Kajian Ilmu dan Budaya Islam 3.1 (2020): 123-136.

Rusyd Muhammad Ibn Ahmad ibn Bidayatu al-Mujtahid wa Nihayatu al-Muqtasid. Beirut: Dar al-Ma'rifah. T.th.

Srinita, "Strategi Menihilkan Korupsi di Sektor Pendidikan dan Kesehatan", Jurnal Kajian Politik Dan Masalah Pembangunan 12, no. 2 (2016): 1898.

Susan, Rose-Ackerman, Corruption and Government: Causes, Consequences, and Reform. New York: Cambridge University Press, 1992.

Syamsuddin. Aziz. Tindak Pidana Khusus. Jakarta: Sinar Grafika, 2011.

Waluyo, Bambang "Kejaksaan Agung Republik Indonesia” Optimalisasi Pemberantasan Korupsi Di Indonesia”, Jurnal Yuridis 1, no. 2 (2014): 174.

Yasin, Muhammad Na'im Kitab al-Iman: Arkanuhu, Haqiqatuhu, Nawaaqiduhu. Iskandariyah: Dar Umar ibn al-Khattab, t.th.

. arkanuhu, haqiqatuhu, nawaqiduhu. Amman Yordania: Dar al-Furqon, 1424 H), 